\begin{tabular}{|c|c|c|}
\hline $\begin{array}{l}\text { 2. To: (Receiving Organization) } \\
\text { Consequenco Analyais (8M400) }\end{array}$ & $\begin{array}{l}\text { 3. From: (Originating Organization) } \\
\text { Consequence Analyeis (BM400) }\end{array}$ & $\begin{array}{r}\text { 4. Related EDT No.: } \\
\text { NA }\end{array}$ \\
\hline $\begin{array}{l}\text { 5. Proj./Prog./Dept./Div.: } \\
8 \mathrm{M400}\end{array}$ & $\begin{array}{l}\text { 6. Cog. Engr.: } \\
\text { T. B. Powers }\end{array}$ & $\begin{array}{c}\text { 7. Purchase Order No.: } \\
\text { NA }\end{array}$ \\
\hline \multirow{2}{*}{\multicolumn{2}{|c|}{$\begin{array}{l}\text { 8. Originator Renarks: } \\
\text { This calculation note replaces calculation note } \\
\text { M-CLC-G-00237 in its entirety. } \\
\text { This calculation note was originally developed and approved } \\
\text { by Westinghouse Savannah River Site (WSRS) personnel but has } \\
\text { been revised since version } 3 \text { and is being submitted for } \\
\text { approval and release into the Hanford document control } \\
\text { system. } \\
\text { Calculation notes are used to document the originator's } \\
\text { analysis but are not to be used as the final or sole } \\
\text { document to authorize activities or justify facility } \\
\text { modifications. }\end{array}$}} & $\begin{array}{l}\text { 9. Equip./Component No.: } \\
\text { NA }\end{array}$ \\
\hline & & 10. Systen/Bldg./Facility: \\
\hline \multirow{3}{*}{\multicolumn{2}{|c|}{$\begin{array}{l}\text { 11. Receiver Renarks: } \\
\text { NA }\end{array}$}} & $\begin{array}{l}\text { 12. Major Assm. Dwg. No.: } \\
\text { NA }\end{array}$ \\
\hline & & $\begin{array}{l}\text { 13. Permit/Permit Applicetion Mo.: } \\
\text { NA }\end{array}$ \\
\hline & & $\begin{array}{l}\text { 14. Required Response Date: } \\
\text { NA }\end{array}$ \\
\hline
\end{tabular}

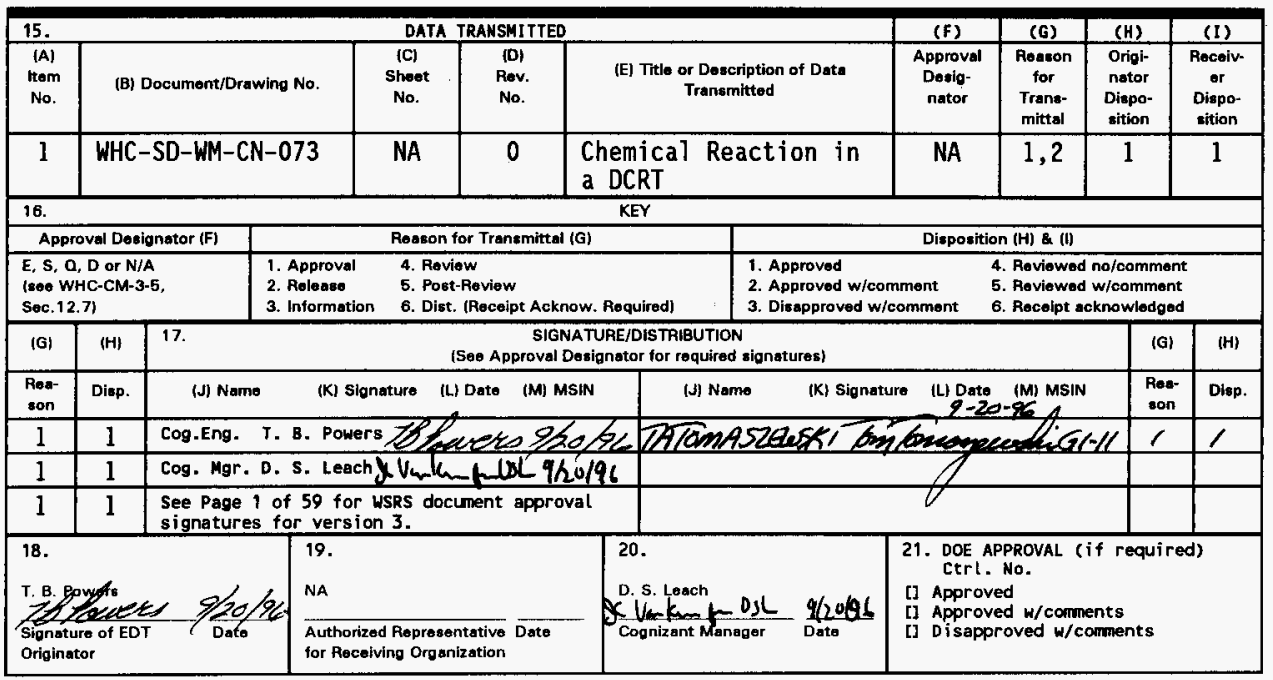




\section{Chemical Reaction in a DCRT}

\section{T. B. Powers}

Westinghouse Hanford Company, Richland, WA 99352

U.S. Department of Energy Contract DE-AC06-87RL10930

$\begin{array}{lll}\text { EDT/ECN: } & \text { EDT-619402 } & \text { UC: } 510 \\ \text { Org Code: } & 8 M 400 & \text { Charge Code: } \\ \text { B\&R Code: } & \text { EW3120071 } & \text { Tota1 Pages: } 60\end{array}$

Key Words: DCRT, double contained receiver tank, acid addition, ammonia, radioactive materials, TWRS, tank farms, ventilation system

Abstract: This document supports the development and presentation of the following accident scenario in the TWRS Final Safety Analysis Report:

\section{Mixing of Incompatible Materials - Tank Pressurization.}

The calculations needed to quantify the risk associated with this accident scenario are included within.

TRADEMARK DISCLAIMER. Reference herein to any specific comercial product, process, or service by trade name, trademark, manufacturer, or otherwise, does not necessarily constitute or imply its endorsement, recommendation, or favoring by the United States Goverrment or any agency thereof or its contractors or subcontractors.

Printed in the United States of America. To obtain copies of this document, contact: WHC/BCS Document Control Services, P.O. Box 1970, Mailstop H6-08, Richland WA 99352, Phone (509) 372-2420; Fax (509) 376-4989.
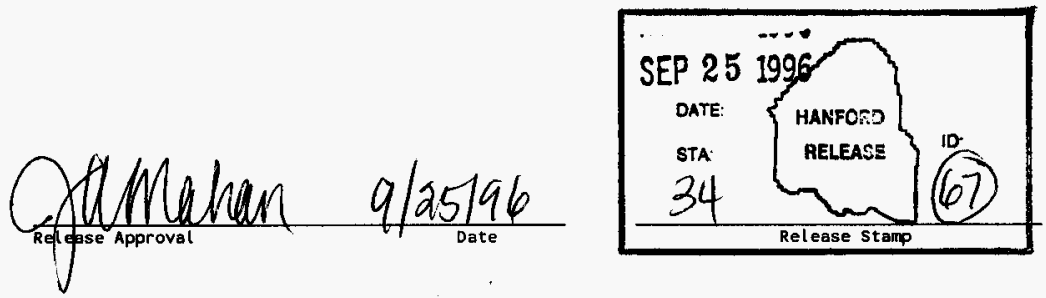

Approved for Public Release 


\section{Calculation Cover Sheet}

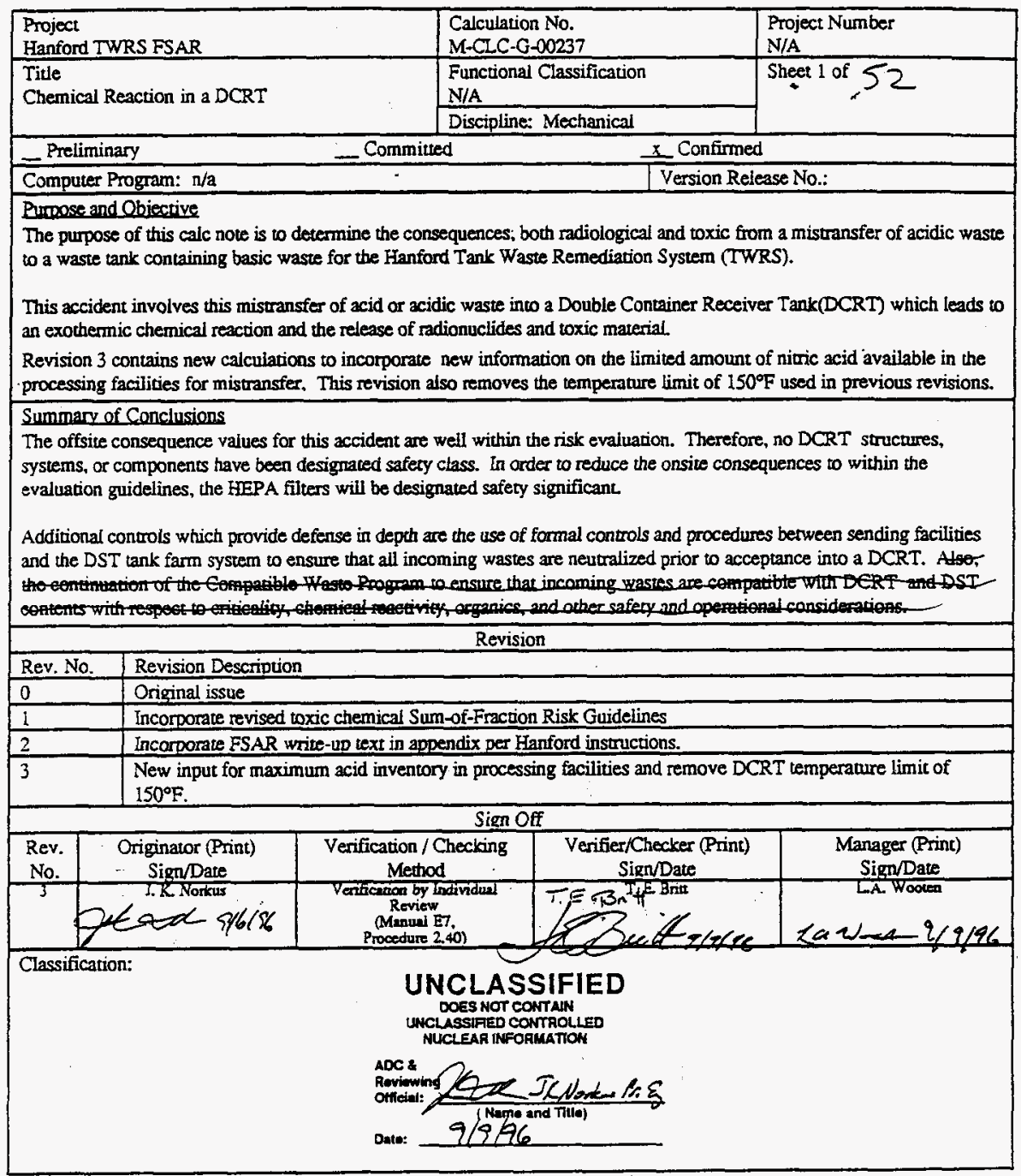


TABLE OF CONTENTS

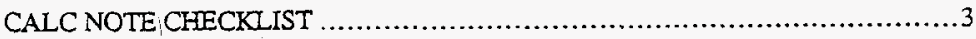

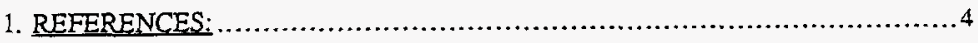

2. INTRODUCTION

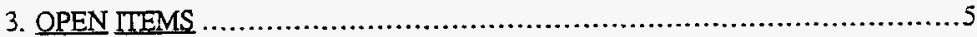

4. INPUT

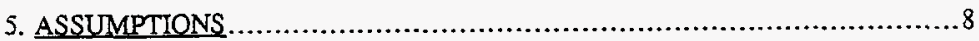

6. ANALYTICAL METHODS AND CALCULATIONS: ..........................10

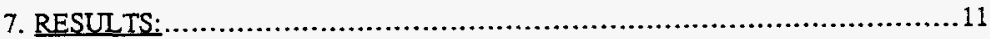

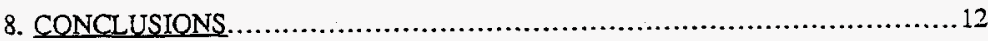

9. APPENDICES .................................................................. 12

TWRS SAR Section Mixing of Incompatible materials - Tank Pressurization, Response to comments

FAX, Craig Carro to Ron Graves, "Comments on WSRC FSAR text for Hanford TWRS SAR," 7/30/96

Ronald Graves, "Information Validation Form, RDG.3 IVF-Chapter 3, June 13, 1996

Calculations 


\section{CALC-NOTE CHECKLIST}

REVIEWER(S):

NAME (PRUNT OR TYPE)

\section{T. E. Britt}

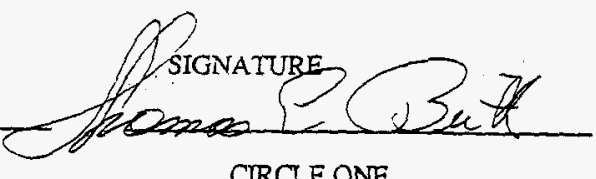

\section{DATE

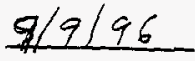

\section{CIRCLE ONE}

1. Is the Subject and/or Purpose clearly stated?

2. Are the required Input Data and their references and source provided and are they consistent with the Calc-Note purpose?

3. Are the Assumptions clearly identified, valid and consistent with the Calc-Note purpose?

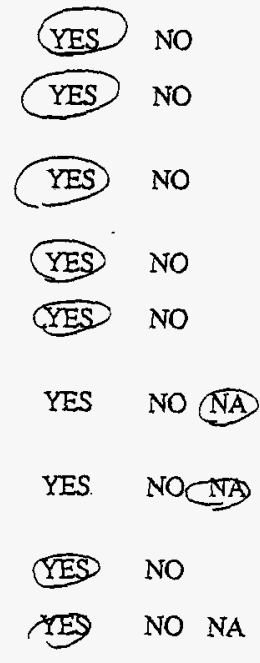

4. Is the Analytical Method or Approach Used clearly identified?

5. Are all the pages consecutiveiy numbered and identified by the Calc-Note number?

6. Is/are the version(s) of the computer program(s) used identified and $Q A ' d$ adequately?

7. Are input listings for all computer programs documented in this Calc-Note, and are they V\&Vd and appropriate for the intended use?

8. Are the Results and Conclusions clearly stated?

9. Are OUTPUT documents included (or if not part of the calculation, clearly referenced in the Results section?) grammatically, correct, clear, and consistent with the main calc-note text?

10. Are the results, methods, input, and assumptions compatible with the stated purpose? PES NO IF NO TO ANY OF THE ABOVE, LIST SHEET NUMBER(S) WITH JUSTIFICATION AND OBTAN MANAGER'S SIGNATURE BELOW:

\section{Manager's Signature}

REVTEWER'S NOTES (use additional pages as necessary)

Review method used: Y $N$
Alternate calculation Artached?

Approximated Originator steps 


\section{BEEERENCES:}

1. WHCa, "Operating Specifications for the 241-AN, AP, AW, AY, AZ, and SY Tank Farms," OSD-T-151-00007, Rev. H-17, 2/8/96, Westinghouse Hanford Co.

2. WHCb, "Operating Specifications for the Saltwell Receiver Tanks," OSD-T-15100011 , Rev. C-3, 9/27/94

3. DOE, Airborne Release Fractions/Rates and Respirable Fractions for non Reactor Nuclear Facilities, DOE-HDBK-3010-94, December 1994.

4. Crowley, W. L., D. L. Herting, D. A. Himes, D. A. Reynolds, T. S. Vail, J. C. Van Keuren, L. P. Leach, and J. York, 1996, Development of Radiological Concentrations and Unit Liter Doses for TWRS FSAR Radiological Consequence Calcularions, WHC-SD-WM-SARR-037, Westinghouse Hanford Company, Richland, Wa.

5. ĐOE, 1994, Aitborne Release FractionstRates and Respirabte Fractions for

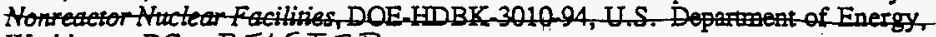
Washingtonde DELET.ED.

6. Van Keuren, J. C, 1996, "Tank Farm Compositions and Amosphere Dispersion Coefficients for Use in Safety Analysis Consequence Assessments", WHC-SDWM-SARR-016, Rev. 2, Westinghouse Hanford Co., Richland WA.

7. Van Keuren, J. C.,1996, "Toxic Chemical Considerations for Tank Farm Releases", WHC-SD-WM-SARR-011, Rev. 2, Westinghouse Hanford Company, Richland, Wa.

8. Weast, R. C., CRC Handbook of Chemistry and Physics, 67th ed., 1986, CRC Press

9. Perry, R. H., and C. H. Chilton, The Chemical Engineers' Handbook, 5th ed, 1973, McGraw Hill

10. RYAN, G.W., 1994, "OPERATIONAL SUMMARIES FOR AUXILIARY FACILITIES", WHC-SP-WM-SARR-DOD, REVO, WESTINGHOUSE HANFORD COMPANY, BCHKAND, WA.

11. WHCC, M94, "TANK FARM SAMPLNG SWSTEM CONFIGUBATON AND EFFICIENCY STUP," REV.', WESTINGHOUSE HANFOPD COMPANV, RICHLAND, WA.

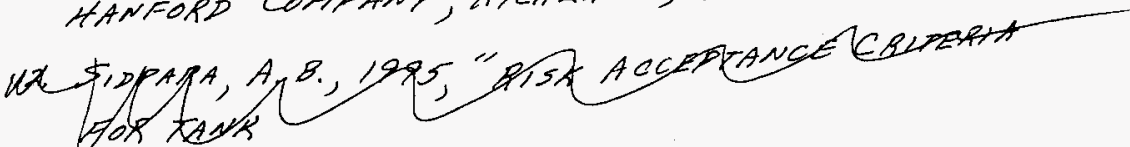

12, hETTER FPOM KINZER TO TREGO, "TNTERIM RADIOLOGNAL DOSE ACCEPTANCE CPITEPIA FOR THE HANFORD TANK FARMS SAFETH ANALYST" $96-M 5 D-069$, APRIL \& 1996. 13. VAN VUEET, R.J., 1993 , "PAPIONUCKIDE AND CHEMICAL TNVENTOPIES FOP THE DOUBLE SHELL TANAS" WAC-SDWM- TI-543, REV' 4 WETNGHOUSE HANEORD COMPANY, RICHLAND WA. 
WHC-SD-WM-CN-073, REV. 0

\section{INTRODUCTION}

The purpose of this caic note is to determine the consequences, both radiological and toxic from a mistransfer of acidic waste to a waste tank containing basic waste for the Hanford Tank Waste Remediation System (TWRS).

This accident involves this mistransfer of acid or acidic waste into a Double Container Receiver Tank (DCRT) which leads to an exothermic chemical reaction and the release of radionuclides and toxic material.

A DCRT is a short-term waste storage facility that consists of an underground concrete structure that contains a filter pit, pump pit, and a vault in which a catch onk is installed. The DCRT is used for interim storage of liquid waste and as a valve pit for waste transfer operations. Components for mixing steam and water for backflushing and decontamination operacions are located in a nearby flush pic.

The exhaust fans in the tank ventilation systems keep a negative air pressure inside the primary tank to prevent unfiltered air emissions from escaping from the DCRT/catch 
station. The air exhausted from the tank passes through a heater, prefilter, HEPA filters, and is monitored for radiation before being released into the environment.

The hazard analysis performed for incompatible waste issues identified a mistransfer of incompatible waste in a DCRT leading to a chemical reaction release radioactive and toxic aerosols as an accident with potentially significant onsite consequences.

WIrH \& WITHOUT

To assess the potential consequences engineered, mitigative systems, a transfer of 100 gallons of 57 weight percent nitric acid into a DCRT was analyzed. A nitric acid transfer was used because:

- Processing facilities contain small amounts of nirric acid, mostly in laboratory scale or 55 gallon drums used for decontamination purposes. A 110 gallon mistransfer of $57 \mathrm{wt} \%$ nitric acid would bound the transfer from any single source.

- Processing facilities are required to neutralize acidic wastes prior to transfer. Unneutralized wastes would be much more dilute than nitric acid. The only facility identified which has substantial amounts of acidic waste was 222-S labs which has a 4000 gallon tank which is connected to the tank farm. Waste contained in this tank could have an unnueralized $\mathrm{pH}$ of $1\left(\mathrm{LH}^{*}\right]$ $=1 \mathrm{M}$ ).

This accident has been analyzed as being an anticipated event.

The material at risk to be released is based on the maximum radionuclide content for onethird double shell solids and two thirds double shell liquids. In practice, there is very little DST solids transferred into DCRTs. Therefore, this is a very conservative assumption.

Revision 3 contains new calculations to incorporate new information on the limited amount of nitric acid available in the processing facilities for mistransfer. This revision aiso removes the temperature limit of $150^{\circ} \mathrm{F}$ used in previous revisions.

\section{OPEN ITEMS}

None.

\section{INPUT}

\subsection{Double Contained Receiver Tank Corrosion Protection Limits}

For wastes in with $\mathrm{NO}_{3}<1.0 \mathrm{M}$ the upper limit on $\left[\mathrm{OH}^{-}\right]$is $5.0 \mathrm{M}$ For wastes which $\mathrm{NO}_{3}$ ' $>1 \mathrm{M}$, the $\left[\mathrm{OH}^{-}\right]$upper limit is $10 \mathrm{M}[1,2]$

\subsection{Airborne Release Fraction (ARE) Boiling Liquid}

The airbome release fraction for boiling of liquid waste is $2 \times 10^{-3}$ [3]. 
WHC-SD-WM-CN-073, REV. 0

Calc Note M-CLC-G-00237 (Rev 3)

Sheet 6

\subsection{DCRT Volume}

\begin{tabular}{cc}
\hline DCRT & Volume (gal) \\
\hline $244-S$ & 20,280 \\
\hline $244-T X$ & 31,000 \\
\hline $244-$ & 31,000 \\
\hline $244-A$ & 16,280 \\
\hline $244-B X$ & 31,000 \\
\hline
\end{tabular}

The volume for DCRT 244-A will be used in this calcularion since it is the minimum volume and will thereby lead to a maximum concentration of radionuclides and toxics. THe OF DCRTS ARE FOUND IN BEFERENCE 10, APPENDIXA.

4.4. DCRT Ventilation Svstem

\begin{tabular}{cc}
\hline DCRT & $\begin{array}{c}\text { Ventilation } \\
\text { Rate (cfm) }\end{array}$ \\
\hline $244-S$ & 165 \\
\hline $244-T X$ & 250 \\
\hline $244-\mathrm{L}$ & \\
\hline $244-\mathrm{A}$ & 150 \\
\hline $244-\mathrm{BX}$ & 250 \\
\hline
\end{tabular}

The ventilarion system in the DCRT draws from the cell and the catch tank. There are not, however, engineered ventilation flow paths from the catch tanks. Any release from the carch tank is from leakage in penetrations. It will be assumed that the entire venvilation flow rate is from the carch tank. This will maximize the source concentration for toxic consequence calculations. THE PCRT VEWTILATION PATES ARE FOUND IN REFERENCE 11.

The filtration efficiency of a HEPA filter is $99.95 \%$ [2].

\subsection{Heats of Eormation}

The heat of formation of the reactants and products of the reaction:

$$
\mathrm{NaOH}(\mathrm{aq})+\mathrm{HNO}_{3} \rightarrow \mathrm{NaNO}_{3}+\mathrm{H}_{2} \mathrm{O}
$$

and the resulting heat of reaction for the neutralization reaction is given by:

$$
\Delta H_{r}=\sum_{p \text { produres }} \Delta H_{f}^{o}-\sum_{\text {reac un } u} \Delta H_{f}^{\circ}
$$


WHC-SD-WM-CN-073, REV. 0

Calc Note M-CLC-G-00237 (Rev 3)

Sheet 7

\begin{tabular}{|c|c|c|}
\hline & $\Delta \mathrm{H}_{\mathrm{f}}^{0}, \mathrm{kcal} / \mathrm{g}$-mole [8] & $\Delta \mathrm{H}_{\mathrm{f}}^{0}, \mathrm{kcal} / \mathrm{g}$-mole[9] \\
\hline $\mathrm{HNO}_{3}$ & -49.37 & -49.21 \\
\hline $\mathrm{NaOH}$ & -112.24 & -112.193 \\
\hline $\mathrm{H}_{2} \mathrm{O}$ & -68.32 & -68.317 \\
\hline $\mathrm{NaNO}_{3}$ & -106.65 & -106.88 \\
\hline \hline Heat of Reaction & $-55.9-13.36$ & $-57.75-13.79$ \\
\hline
\end{tabular}

The data from Ref. 9, which yield a larger energy release will be used for this calculation.

\subsection{Unit Liter Dose-DST [4]}

\begin{tabular}{|l|c|c|}
\hline \multicolumn{1}{|c|}{ Composite } & $\begin{array}{c}\text { Inhalarion ULD } \\
(\mathrm{Sv} / \mathrm{L})\end{array}$ & $\begin{array}{c}\text { Ingestion ULD* } \\
\left(\mathrm{Sv}-\mathrm{m}^{3} / \mathrm{s}-\mathrm{L}\right)\end{array}$ \\
\hline Double-shell tank liquids & $6.1 \mathrm{E}+03$ & 0.068 \\
\hline Double-shell tank solids & $5.3 \mathrm{E}+05$ & 0.48 \\
\hline
\end{tabular}

\subsection{Toxicological Exposure = Sum of Eractions Values. [7]}

Radiological risk guidelines are quantified in terms of single dose value which can be determined and summed for all types and energies of radiation. In contrast, toxicological risk guidelines are specific to individual chemicals. To account for exposure to all chemicals contained in a release, sum-of-fractions values were calculated in Ref. 7 . The basic steps used to determine sum-of-fractions values for a continuous release of solids or liquids were:

1. Assume that a continuous release of $1 \mathrm{~L} / \mathrm{sec}$ occurs

2. Assume that each of the chemical constituents of the composite tank inventories are contained within the release.

3. Calculate the peak concentration at the receptor of interest.

4. Divide the peak concentration for each analyte by the risk grideline concentration limit value for that analyte, given the location of the receptor and the frequency of the scenario. This yields a fraction of the limit. 
5. Sum individual fractions to give the sum-of-fraction values.

Sum-of-Fractions for Unit Releases of Solids and Liquids.[7]

\begin{tabular}{|l|c|c|c|c|}
\hline \multirow{3}{*}{$\begin{array}{c}\text { Tank Waste } \\
\text { Type }\end{array}$} & \multirow{2}{*}{$\begin{array}{c}\text { Maximum } \\
\text { Individual }\end{array}$} & \multicolumn{3}{|c|}{$\begin{array}{c}\text { Sum-of-Fractions (s/L) as a function of } \\
\text { Accident Frequency (1/yr) }\end{array}$} \\
\cline { 3 - 5 } & & $1-10^{-2}$ & $10^{-2}-10^{-7}$ & $10^{-7}-10^{-6}$ \\
\hline \multirow{2}{*}{ DST liquids } & DST solid or liquid continuous release \\
& Onsite & $1.0 \mathrm{E}+04$ & $7.5 \mathrm{E}+02$ & $2.1 \mathrm{E}+02$ \\
\cline { 2 - 5 } & Offsite & $8.4 \mathrm{E}+00$ & $8.4 \mathrm{E}+00$ & $6.2 \mathrm{E}-01$ \\
\hline DST solids & Onsite & $1.8 \mathrm{E}+004$ & $3.3 \mathrm{E}+03$ & $6.3 \mathrm{E}+02$ \\
\cline { 2 - 5 } & Offsite & $1.9 \mathrm{E}+02$ & $1.5 \mathrm{E}+01$ & $2.8 \mathrm{E}+0$ \\
\hline
\end{tabular}

4.8. Atmospheric Disoersion Eactors [6] TAB2ES 495 .

Centerline Amospheric Dispersion Coefficients for a 200-Area Tank Farm Acute, Ground Level Release.

\begin{tabular}{|c|c|}
\hline Maximum Individual & $\begin{array}{c}\text { Bounding Integrated } \chi / \mathrm{Q}^{\prime} \\
\left(\mathrm{s} / \mathrm{m}^{3}\right)\end{array}$ \\
\hline Onsite Sector and distance & $3.41 \mathrm{E}-02 \mathrm{E} 100 \mathrm{~m}$ \\
\hline Offsite Sector and distance & $2.83 \mathrm{E} / 11,100 \mathrm{~m}$ \\
\hline 4.2. Breathing Rates & $N 8,760 \mathrm{~m}$ \\
\hline
\end{tabular}

For the maximum onsite individual, the light activity breathing rate is used, i.e., $3.3 \times 10^{-4}$ $\mathrm{m}^{3} / \mathrm{s}$. For the maximum offsite individual, the $24-\mathrm{hr}$ average breathing rate is used, i.e., $2.7 \times 10^{4} \mathrm{~m}^{3} / \mathrm{s}$. THESE VALUES ARE FOOND NN REFERENCE $L$,

4.10. Dose limits .

\begin{tabular}{|l|c|c|c|}
\hline \multirow{2}{*}{ Receptor/Hazard } & \multicolumn{3}{|c|}{ Risk Guidelines } \\
\cline { 2 - 4 } & Anticipated & Unilikely & $\begin{array}{c}\text { Extremely } \\
\text { Unlikely }\end{array}$ \\
\hline Off-Site/Radiological & $0.1 \mathrm{rem}$ & $.5 \mathrm{rem}$ & $4 \mathrm{rem}$ \\
\hline On-Site/Radiological & $.5 \mathrm{rem}$ & $5 \mathrm{rem}$ & $10 \mathrm{rem}$ \\
\hline $\begin{array}{l}\text { Off-Site/ } \\
\text { Toxicological }\end{array}$ & 1 & 1 & 1 \\
\hline $\begin{array}{l}\text { On-Site/ } \\
\text { Toxicological }\end{array}$ & 1 & 1 & 1 \\
\hline
\end{tabular}

5. ASSUMPTIONS

\subsection{Acidic Waste}

The acidic waste is assumed to be 57 wt $\%$ nitric acid (12 MD. The waste which is shipped to the TWRS tanks will be much more dilute, therefore, this is a bounding value. Response to an Information Validation Form(see Appendix) on nitric acid inventories in processing facilities connected to TWRS indicates very limited quantities of nitric acid and 


$$
\text { WHC-SD-WM-CN-073, REV. } 0
$$

acidic waste. The maximum acidic waste transfer is assumed to be 110 gallons. This is the maximum allowed in any of the processing facilities connected to the TWRS [B-Plant].

Also, a transfer of 4000 gallons of unnuetralized acidic waste $\left(\mathrm{pH}=1,\left[\mathrm{H}^{+}\right]=.1 \mathrm{M}\right)$ will be analyzed.

\subsection{Basic Waste}

The accident scenario assumes that the DCRT contains waste which is sufficiently basic to completely neutralize the incoming acid transfer

$$
\mathrm{V}_{\text {wams }}=\frac{\left[\mathrm{H}^{+}\right]_{\text {edde }} \mathrm{V}_{\text {ocd }}}{\left[\mathrm{OH}^{-}\right]_{\text {wase }}}
$$

This ensures that the maximum heat of reaction per mole of incoming acid is generated and maximizes the heatup of waste. The hydroxide content is taken to be at the maximum allowed under DCRT corrosion control limits (10 $\left.\mathrm{M} \mathrm{OH}^{-}\right)$. The material at risk is thereby defined by this amount.

\subsection{DCRT Radiological and Texic Inventory}

The radiological and toxicological inventory is assumed to be $2 / 3$ DST liquids and $1 / 3$ DST solids.

\subsection{Waste Temperature}

The waste is assumed to be at $200^{\circ} \mathrm{F}\left(93^{\circ} \mathrm{C}\right)[\not 6]$. This is the maximum allowable temperature for DCRTs based on thermal structural considerations.

\subsection{Yentilation svstem}

The ventilation rate is assumed to be $250 \mathrm{cfm}_{1}$ which is the maximum flow rate for the DCRTs considered (244-TX). No credit for HEPA filters is taken for the unmitigated case. For the mitigated case, a filtration efficiency of $99.95 \%$ is used (LPF=SE-4).

\subsection{Heat Transfer}

The DCRT heatup is assumed to be adiabatic and instantaneous. All energy produced from the exothermic acid/base neurralization reaction will be assumed to heat up the waste instantaneously. No energy will be transferred from the DCRT.

The assumed instantaneous heat up is very conservarive since the addition of waste to he tank at 100 gpm would occur over 10 to 40 minutes, depending on the total transfer volume. These assumptions maximize the amount of material which could be released to the environment.

\subsection{Release Period}

The release is assumed to last less than one hour. 


\subsection{Processing Facilites Acid Inventory}

This table summarizes the availble inventory of nitric acid on processing facilities which might mistransfer material to the tank farms.

\begin{tabular}{|l|l|}
\hline Facility & Amount of Nitric Acid \\
\hline B-Plant & 110 gallon, maximum safety basis limit \\
\hline PFP & $\begin{array}{l}\text { None stored. Maximum } 110 \text { gallon } \\
\text { allowed. }\end{array}$ \\
\hline $222-S$ & Not connected directly to tank farm \\
\hline PUREX & None. \\
\hline
\end{tabular}

\section{ANALYTICAL METHODS AND CALCULATIONS:}

\subsection{Method}

\subsubsection{Dose Calculation Methods}

The first step in calculating the dose is to derive the airborne source term, i.e., the amount of airbome radioactive material generated by the accident that is available for transport to the maximum onsite and offsite individuals. The airborne source term is estimated by the following formula:

$$
\begin{array}{rlrl}
\text { Source Term } & =\text { MAR } \times \text { DR } \times \text { ARF } \times R F \times L P F \\
\text { where: } & \text { MAR } & = & \text { Material-at-Risk } \\
\text { DR } & = & \text { Damage Ratio } \\
\text { ARF } & = & \text { Airbome Release Fraction, or Airborne Release Rate } \\
& \text { RF } & = & \text { (ARR) for continuous releases } \\
\text { LPF } & = & \text { Respirable Fraction } & \text { Leakpath Factor. }
\end{array}
$$

Given an airbome source term, the doses from the inhalation and ingestion pathways are calculated by the following formulas:

Inhalarion:

$$
D_{\text {ien }}(S v)=Q(L) \times \frac{\chi}{Q}\left(\frac{s}{m^{3}}\right) \times R\left(\frac{m^{3}}{s}\right) \times U L D_{\text {inh }}\left(\frac{S v}{L}\right)
$$

Ingescion:

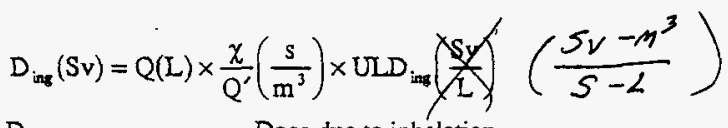

$$
\text { where: } \quad \begin{array}{lll}
\mathrm{D}_{\text {inh }} & = & \text { Dose due to inhalation } \\
\mathrm{D}_{\text {ing }} & = & \text { Dose due to ingestion } \\
\mathrm{Q}^{\mathrm{n}} & = & \text { Respirable source term } \\
\chi / \mathrm{Q}^{\prime} & = & \text { amospheric dispersion coefficient } \\
\mathrm{R} & = & \text { Breathing rate }
\end{array}
$$




$$
\begin{array}{lll}
\text { ULD }_{\text {inh }} & = & \text { Inhaladion Unit liter dose } \\
\text { ULD }_{\text {ing }} & = & \text { Ingestion Unit liter dose. }
\end{array}
$$

\subsection{Toxicological Consequence Calculation Methodology.}

Comparison of toxicological consequences to the WHC risk guidelines is made as follows:

1. Determine the accident frequency range of the accident.

2. Determine the type of material being released (i.e., SST solids, SSTs liquids, etc.).

3. Determine whether the release is continuous or instantaneous

4. Determine the release quantity or release rate, i.e., the airborne source term. This is performed in the same manner as for radioactive materials.

5. Multiply the release quantity or release rate determined in step 4 by the appropriate value from the table in section 4.7. Products less than or equal to one indicate that the WHC risk guidelines are met

For a continuous release of solid or liquid toxic material, the peak concentration is calculated using the following equation:

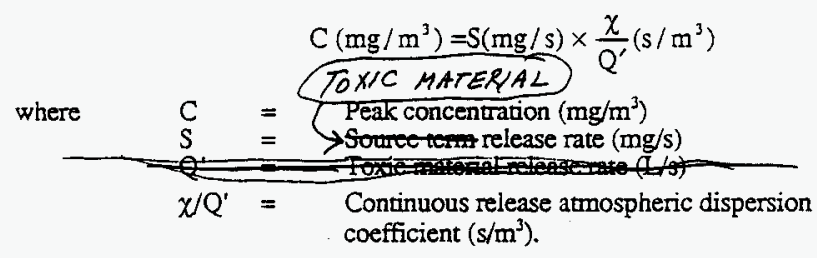

\section{RESULTS:}

The results for the addition of 110 gallons, 57 weight percent nitric acid and 4000 gal of acidic waste $(\mathrm{pH}=1)$ into a sufficient amount of basic waste are displayed below. The results are for unmitigated and mitigated (HEPA filters). For the unmitigated case, the offsite doses for both radiological and toxics are below the evaluation guidelines. For the onsite doses, the results are above the evaluation guidelines for the nirric acid addition.

Note that the radiological consequences are expressed in sieverts, whereas the calculations are performed in rem. The conversion from rem to sieverts is 100 rem for every seivert. 
Sample Calculation Related to Acid Addition to DCRT, Unmitigated (sample results may differ from spreadsheet values due to round off)

The analysis starts with 110 gallons of 57 weight percent nitric acid $\left(57 \% \mathrm{HNO}_{3}\right.$ ) at 12.2 molarity $(\mathrm{M})$. This 110 gallons is converted to 1 iters.

Step 1:

$$
110 \text { gallons } * 3.785411 \text { liters } / \text { gallon }=4.164 E+21 \text { iters }
$$

It is assumed that there is only as much waste in the DCRT as will completely react with the $110 \mathrm{gall}$ gons of $\mathrm{HNO}_{3}$. This volume of $57 \% \mathrm{HNO}_{3}$ neutralizes the following volume of $10 \mathrm{M}$ basic waste.

Step 2:

$$
\text { 4.164E+2 liters * }(12.2 \mathrm{M} \div 10 \mathrm{M})=5.080 \mathrm{E}+2 \text { 1iters }
$$

Therefore the total volume of acid and waste involved in the reaction is calculated and converted to cubic meters $\left(\mathrm{m}^{3}\right)$.

Step 3:

$$
(4.164 \mathrm{E}+2+5.080 \mathrm{E}+21 \text { iters }) *\left(1 \mathrm{~m}^{3} / 1000 \text { liters }\right)=0.9244 \mathrm{~m}^{3}
$$

The heat of reaction is the larger of the two heat of reactions per gram-mole from the table in Section 4.5 converted to Joules (J) per gram-mole.

Step 4:

$$
-13.79 \mathrm{kcal} / \mathrm{gram}-\mathrm{mole} * 4185 \mathrm{~J} / \mathrm{kcal}=-5.771 \mathrm{E}+4 \mathrm{~J} / \mathrm{gram}-\mathrm{mole}
$$

The reaction energy in Joules (J) is calculated using the acid molarity $(12.2 \mathrm{M})$, the volume of acid from Step 1 , and the heat of reaction per mole from Step 4.

Step 5:

$\mid 12.2$ gram-moles/1iter * $4.164 \mathrm{E}+2$ liters * $-5.771 \mathrm{E}+4 \mathrm{~J} / \mathrm{gram}-\mathrm{mole} \mid=2.932 \mathrm{E}+8 \mathrm{~J}$ 
The temperature increase of the chemical reactants in degrees Kelvin ( ${ }^{\circ} \mathrm{K}$ ) is calculated using reaction energy from Step 5 , volume of waste from Step 3 , density of water as representing the waste $\left(1000 \mathrm{~kg} / \mathrm{m}^{3}\right)$, heat capacity of water $\left(4200 \mathrm{~J} / \mathrm{kg}-\mathrm{m}^{3}\right)$.

Step 6:

$$
(2.932 \mathrm{E}+8 \mathrm{~J}) /\left(0.9244 \mathrm{~m}^{3} * 1000 \mathrm{~kg} / \mathrm{m}^{3} * 4200 \mathrm{~J} / \mathrm{kg}-{ }^{\circ} \mathrm{K}\right)=75.52{ }^{\circ} \mathrm{K} \text { or }{ }^{\circ} \mathrm{C}
$$

The temperature increase is added to the initial temperature of the waste and acid which is conservatively assumed to be $93.33^{\circ} \mathrm{C}\left(200^{\circ} \mathrm{F}\right)$ to determine if the chemical reactants reach boiling (which is assumed to be $100^{\circ} \mathrm{C}$ ).

Step 7:

$$
75.52{ }^{\circ} \mathrm{C}+93.33{ }^{\circ} \mathrm{C}=168.9{ }^{\circ} \mathrm{C} \geq 100{ }^{\circ} \mathrm{C} \text { therefore boiling }
$$

The heat necessary to raise the chemical reactants from $93.33{ }^{\circ} \mathrm{C}$ to $100{ }^{\circ} \mathrm{C}$ is calculated using the density of water $\left(1000 \mathrm{~kg} / \mathrm{m}^{3}\right)$, heat capacity of water $\left(4200 \mathrm{~J} / \mathrm{kg}-\mathrm{m}^{3}\right)$, the volume of waste from Step 3 , and the temperature difference between $93.33^{\circ} \mathrm{C}$ and $100{ }^{\circ} \mathrm{C}$.

Step 8:

$$
1000 \mathrm{~kg} / \mathrm{m}^{3} * 4200 \mathrm{~J} / \mathrm{kg}-{ }^{\circ} \mathrm{C} * 0.9244 \mathrm{~m}^{3} *\left(100{ }^{\circ} \mathrm{C}-93.33^{\circ} \mathrm{C}\right)=2.590 \mathrm{E}+7 \mathrm{~J}
$$

The amount of chemical reactant solution that can be vaporized due to boiling is calculated using the total reaction energy from Step 5 , the energy required to raise the chemical reactants to $100^{\circ} \mathrm{C}$ from Step 8 , and the heat of vaporization for water $(2,256,900 \mathrm{~J} / \mathrm{kg})$.

Step 9:

$$
(2.932 \mathrm{E}+8 \mathrm{~J}-2.590 \mathrm{E}+7 \mathrm{~J}) /(2.2569 \mathrm{E}+6 \mathrm{~J} / \mathrm{kg})=118.4 \mathrm{~kg}
$$


The volume of chemical reactant solution vaporized js calculated using the amount from Step 9, the density of water $\left(1000 \mathrm{~kg} / \mathrm{m}^{3}\right)$, and conversion from $\mathrm{m}^{3}$ to liters.

Step 10:

$$
\left(118.4 \mathrm{~kg} /\left(1000 \mathrm{~kg} / \mathrm{m}^{3}\right)\right) *\left(1000 \text { liters } / \mathrm{m}^{3}\right)=118.4 \text { liters }
$$

The fraction of the initial volume of acid and waste that was waste is calculated using the volumes from Steps 1 \& 2 .

Step 11:

$$
5.080 E+2 \text { liters } /(4.164 E+2 \text { liters }+5.080 E+2 \text { Titers })=0.55
$$

The source term in liters that are released and respirable is calculated using the volume released from Step 10, the fraction of the released volume that was waste from Step 11, an Airborne Release Fraction (ARF) of 2E-3, a Respirable Fraction (RF) of 1.0, and a Leak Path Fraction (LPF) of 1.0. This source term volume is used in the radiological and toxicological calculations.

Step 12:

$$
118.4 \text { liters } * 0.55 * 2 \mathrm{E}-3 * 1.0 * 1.0=0.130 \text { liters }
$$

The onsite inhalation dose in rem (Sv) is calculated using the conversion of $100 \mathrm{rem} / \mathrm{Sv}$, the source term volume from Step 12, the $X / Q$ onsite value $\left(3.41 \mathrm{E}-2 \mathrm{sec} / \mathrm{m}^{3}\right)$, onsite breathing rate $(R)$ value $\left(3.3 \mathrm{E}-4 \mathrm{~m}^{3} / \mathrm{sec}\right)$, the liquid fraction $(0.67)$, inhalation Unit Liter Dose $\left(U L D_{\text {inh }}\right)$ for $D_{\text {STT }}$ liquid value $(6.1 E+3 \mathrm{~Sv} / 1$ iter), the solids fraction $(0.33)$, and the ULD inh for DST solids value of $(5.3 E+5$ Sv/liter $)$.

Step 13:

$$
\begin{aligned}
& 100 \mathrm{rem} / \mathrm{Sv} * 0.130 \text { liters *3.41E-2 sec } / \mathrm{m}^{3} * 3.3 \mathrm{E}-4 \mathrm{~m}^{3} / \mathrm{sec} * \\
& ((0.67 * 6.1 \mathrm{E}+3 \mathrm{~Sv} / 1 \text { iter })+(0.33 * 5.3 \mathrm{E}+5 \mathrm{~Sv} / 1 \text { iter }))=26.18 \mathrm{rem}(0.2618 \mathrm{~Sv})
\end{aligned}
$$


The onsite ingestion dose in rem (Sv) is calculated using the conversion of $100 \mathrm{rem} / \mathrm{Sv}$, the source term volume from Step 12, the $X / Q$ onsite value $\left(3.41 \mathrm{E}-2 \mathrm{sec} / \mathrm{m}^{3}\right)$, the 1 iquid fraction $(0.67)$, ingestion ULD ${ }_{\text {ing }}$ for $D S T_{\text {liquid }}$ value $\left(0.068 \mathrm{~Sv}^{3} / \mathrm{sec}^{3}-1\right.$ ter $)$, the solids fraction $(0.33)$, and the ULD ing for DST $_{\text {solids }}$ value of $\left(0.485 \mathrm{~s}-\mathrm{m}^{3} / \mathrm{sec}-1 \mathrm{iter}\right)$.

Step 14:

$$
\begin{gathered}
100 \mathrm{rem} / \mathrm{Sv} * 0.130 \text { liters } * 3.41 \mathrm{E}-2 \mathrm{sec} / \mathrm{m}^{3} * \\
\left(\left(0.67 * 0.068 \mathrm{~Sv}-\mathrm{m}^{3} / \mathrm{sec}-1 \text { iter }\right)+\left(0.33 * 0.48 \mathrm{~Sv}-\mathrm{m}^{3} / \mathrm{sec}-1 \text { iter }\right)\right)= \\
0.0904 \mathrm{rem}(9.04 \mathrm{E}-4 \mathrm{~Sv})
\end{gathered}
$$

The total onsite dose from inhalation and ingestion is the sum of Steps 13 and 14 .

Step 15:

$$
26.18 \text { rem }+0.09 \text { rem }=26.27 \text { rem }(0.2627 \text { Sv })
$$

The offsite inhalation dose in rem (Sv) is calculated using the conversion of $100 \mathrm{rem} / \mathrm{Sv}$, the source term volume from Step 12, the $X / Q$ offsite value $\left(2.83 \mathrm{E}-5 \mathrm{sec} / \mathrm{m}^{3}\right)$, offsite breathing rate $(R)$ value $\left(2.7 \mathrm{E}-4 \mathrm{~m}^{3} / \mathrm{sec}\right)$, the liquid fraction $(0.67)$, inhalation $\mathrm{ULD}_{\text {inh }}$ for $\mathrm{DST}_{\text {liguid }}$ value $(6.1 \mathrm{E}+3 \mathrm{SV} / \mathrm{liter})$, the solids fraction $(0.33)$, and the $\mathrm{ULD}_{i n h}$ for $\mathrm{DST}_{\text {solids }}$ value of $(5.3 E+5 \mathrm{~Sv} / 1 \mathrm{iter})$.

Step 16:

$$
\begin{gathered}
100 \mathrm{rem} / \mathrm{Sv} * 0.130 \text { liters } * 2.83 \mathrm{E}-5 \mathrm{sec} / \mathrm{m}^{3} * 2.7 \mathrm{E}-4 \mathrm{~m}^{3} / \mathrm{sec} * \\
((0.67 * 6.1 \mathrm{E}+3 \text { Sv } / 1 \text { iter })+(0.33 * 5.3 \mathrm{E}+5 \mathrm{~Sv} / 1 \text { iter }))= \\
1.778 \mathrm{E}-2 \text { rem }(1.778 \mathrm{E}-4 \mathrm{~Sv})
\end{gathered}
$$

The offsite ingestion dose in rem (Sv) is calculated using the conversion of $100 \mathrm{rem} / \mathrm{Sv}$, the source term volume from Step 12, the $x / Q$ offsite value $\left(2.83 E-5 \mathrm{sec} / \mathrm{m}^{3}\right)$, the liquid fraction $(0.67)$, ingestion ULD ${ }_{\text {ing }}$ for $\mathrm{DST}_{\text {liquid }}$ value $\left(0.0685 \mathrm{~Sv} \mathrm{~m}^{3} / \mathrm{sec}-1\right.$ iter $)$, the solids fraction $(0.33)$, and the ULD ing for DST $_{\text {solids }}$ value of $\left(0.48 \mathrm{~Sv}-\mathrm{m}^{3} / \mathrm{sec}-1 \mathrm{iter}\right)$.

Step 17:

$$
\begin{array}{r}
100 \mathrm{rem} / \mathrm{Sv} * 0.130 \text { liters } * 2.83 \mathrm{E}-5 \mathrm{sec} / \mathrm{m}^{3} * \\
\left(\left(0.67 * 0.068 \mathrm{~Sv}-\mathrm{m}^{3} / \mathrm{sec}-1 \text { iter }\right)+\left(0.33 * 0.48 \mathrm{~Sv}-\mathrm{m}^{3} / \mathrm{sec}-1 \text { iter }\right)\right)= \\
7.504 \mathrm{E}-5 \text { rem }(7.504 \mathrm{E}-7 \mathrm{~Sv})
\end{array}
$$


The total offsite dose from inhalation and ingestion is the sum of Steps 16 and 17 .

Step 18:

$1.778 \mathrm{E}-2 \mathrm{rem}+7.504 \mathrm{E}-5 \mathrm{rem}=1.786 \mathrm{E}-2 \mathrm{rem}(1.786 \mathrm{E}-4 \mathrm{~Sv})$

The fraction of the headspace that is filled with released waste is calculated using the volume released from Step 12 and the volume of the headspace. The volume of the headspace is calculated by subtracting the volume of acid (Step 1 ) and waste neutralized (Step 2) from the volume of the tank (61,600 1iters). This fraction is used with the toxicological calculations.

Step 19:

$$
(0.130 \text { liters }) /(61,600-416.4-508.0 \text { liters })=2.143 E-6
$$

The toxicological release rate from the DCRT is calculated using the fraction of the headspace volume containing waste and the ventilation rate for the DCRT ventilation system (250 $\mathrm{ft}^{3} / \mathrm{min}$ or 118 liters/sec).

Step 20:

$$
2.143 \mathrm{E}-6 * 118 \text { liters } / \mathrm{sec}=2.529 \mathrm{E}-4 \text { iters } / \mathrm{sec}
$$

The DST liquid release rate is calculated using the release rate from Step 20 and the fraction of waste that is liquids $(0.67)$.

Step 21:

$2.529 \mathrm{E}-4$ liters $/ \mathrm{sec} * 0.67=1.694 \mathrm{E}-4$ iiters $/ \mathrm{sec}$

The DST solids release rate is calculated using the release rate from Step 20 and the fraction of waste that is solids $(0.33)$.

Step 22:

2.529E-4 1iters $/ \mathrm{sec} * 0.33=8.346 \mathrm{E}-5 \mathrm{liters} / \mathrm{sec}$ 
The liquids onsite Sum-of-Fractions (SOF) is calculated using the release rate from Step 21 and the SOF Unit Release for DST liquids onsite related to an anticipated frequency $(1.0 \mathrm{E}+4 \mathrm{sec} / 1 \mathrm{ter})$.

Step 23:

$$
1.694 \mathrm{E}-41 \text { iters } / \mathrm{sec} * 1.0 \mathrm{E}+4 \mathrm{sec} / 1 \text { iter }=1.694
$$

The liquids offsite Sum-of-Fractions (SOF) is calculated using the release rate from Step 21 and the SOF Unit Release for DST liquids offsite related to an anticipated frequency $(8.4 \mathrm{sec} / 1 \mathrm{iter})$.

Step 24:

$1.694 \mathrm{E}-4$ liters $/ \mathrm{sec} * 8.4 \mathrm{sec} /$ liter $=1.423 \mathrm{E}-3$

The solids onsite Sum-of-Fractions (SOF) is calculated using the release rate from Step 22 and the SOF Unit Release for DST solids onsite related to an anticipated frequency (1.8E+4 sec/liter).

Step 25:

$$
8.346 \mathrm{E}-5 \text { 1iters } / \mathrm{sec} * 1.8 \mathrm{E}+4 \mathrm{sec} / 1 \mathrm{iter}=1.502
$$

The solids offsite Sum-of-Fractions (SOF) is calculated using the release rate from Step 22 and the SOF Unit Release for DST solids offsite related to an anticipated frequency $(1.9 \mathrm{E}+2 \mathrm{sec} / 1 \mathrm{iter})$.

Step 26:

$8.346 \mathrm{E}-5$ liters $/ \mathrm{sec} * 1.9 \mathrm{E}+2 \mathrm{sec} / 1 \mathrm{iter}=1.586 \mathrm{E}-2$ 
WHC-SD-WM-CN-073, REV. 0

The onsite SOF for ammonia release (because ammonia is released during the chemical reaction and is not capable of being filtered by HEPA filters) is calculated using a maximum concentration of ammonia in DST waste $(3270$ $\mathrm{mg} / 1$ iter) Reference 13, page D-28, release volume from Step 10 , fraction of release that is waste from Step 11 , volume of the headspace $(60,676$ 1iters), ventilation rate found in Step 20 (118 liters/sec), $x / Q$ onsite value $\left(3.41 \mathrm{E}-2 \mathrm{sec} / \mathrm{m}^{3}\right)$, and the limit for ammonia for an anticipated event expressed as $\mathrm{mg} / \mathrm{m}^{3}\left(17.25 \mathrm{mg} / \mathrm{m}^{3}\right)$ from Reference 7 , page $D-37$.

Step 27:

$$
\begin{aligned}
& {[(3270 \mathrm{mg} / 1 \text { iter } * 118.41 \text { iters } * 0.55) / 60,676 \text { liters }] *} \\
& 1181 \text { iters } / \mathrm{sec} *\left(3.41 \mathrm{E}-2 \mathrm{sec} / \mathrm{m}^{3} / 17.25 \mathrm{mg} / \mathrm{m}^{3}\right)=0.8186
\end{aligned}
$$

The total onsite SOF is calculated using SOF for liquids onsite from Step 23, solids onsite from Step 25, and ammonia onsite from Step 27.

Step 28:

$$
1.694+1.502+0.819=4.015
$$

The offsite SOF for ammonia release is calculated using a maximum concentration of ammonia in DST waste $(3270 \mathrm{mg} / \mathrm{liter})$, release volume from Step 10, fraction of release that is waste from Step 11, volume of the headspace $(60,676$ liters), ventilation rate found in Step 20 (118 1 iters/sec), $x / Q$ offsite value $\left(2.83 \mathrm{E}-5 \mathrm{sec} / \mathrm{m}^{3}\right)$, and the $1 \mathrm{imit}$ for ammonia for an anticipated event expressed as $\mathrm{mg} / \mathrm{m}^{3}\left(17.25 \mathrm{mg} / \mathrm{m}^{3}\right)$ from Reference 7 , page D-37.

Step 29:

$[(3270 \mathrm{mg} / 1$ iter $* 118.4$ liters $* 0.55) / 60,676$ liters $] *$
1181 iters $/ \mathrm{sec} *\left(2.83 \mathrm{E}-5 \mathrm{sec} / \mathrm{m}^{3} / 17.25 \mathrm{mg} / \mathrm{m}^{3}\right)=6.794 \mathrm{E}-4$

The total offsite SOF is calculated using SOF for liquids offsite from Step 24, solids offsite from Step 26, and ammonia offsite from Step 29.

Step 30:

$$
1.423 \mathrm{E}-3+1.586 \mathrm{E}-2+6.794 \mathrm{E}-4=1.796 \mathrm{E}-2
$$


Mitigating the release by use of HEPA filters brings the results within the onsite evaluation guidelines.

\begin{tabular}{|c|c|c|c|c|c|c|c|c|}
\hline \multirow{4}{*}{ Accident } & \multicolumn{8}{|c|}{ Consequences } \\
\hline & \multicolumn{4}{|c|}{ Radiological (Sv) } & \multicolumn{4}{|c|}{ Toxicological } \\
\hline & \multicolumn{2}{|c|}{ Urmitigated } & \multicolumn{2}{|c|}{ Mingated } & \multicolumn{2}{|c|}{ Unmitigated } & \multicolumn{2}{|c|}{ Mitignted } \\
\hline & Ontive & Offuite & Otsite & Offrite & Onnite & Ofinite & Onsite & Offsite \\
\hline $\begin{array}{l}110 \text { gal } 57 \text { us } \\
\text { Nhitic Acid } \\
\text { minumaner }\end{array}$ & .27 & $1.8 \mathrm{E}-04$ & $1,355-04$ & $9.0<08$ & $\frac{3.19}{4,03}$ & $1,816-2$ & $\begin{array}{c}1.590-05 \\
.82\end{array}$ & $\begin{array}{l}967 \mathrm{E} \\
6.98-04\end{array}$ \\
\hline $\begin{array}{l}4000 \text { gal } \\
\text { tranfer, } 222-\mathrm{S} \\
\text { wate, } \mathrm{pH}=1\end{array}$ & 0 & 0 & & - & 0 & $\overline{0}$ & & \\
\hline
\end{tabular}
$N / A=$ not applicable.

$S v=$ sieverts.

\section{CONCLUSION:}

The offsite consequence values for this accident are well within the risk evaluation. Therefore, no DCRT strucures, systems, or components have been designated safery class or safety significant. In order to reduce the onsite consequences to within the evaluation guidelines, the HEPA filters will be designated safety significant.

Additional controls which provide defense in depth is the use of formal controls and procedures between sending facilities and the DST tank farm system to ensure that all incoming wastes are neutralized prior to acceptance into a DCRT. Atso, the contintution of

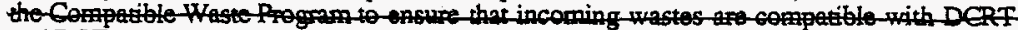
and DSF contents with-respect to-eritieality, ehemient rasctivy, organies, and-other safery aperational considerations.

\section{$2 . \quad$ APPENDICES}

TWRS SAR Section Mixing of Incompatible materials - Tank Pressurization

Response to comments

FAX, Craig Carro to Ron Graves, "Comments on WSRC FSAR text for Hanford TWRS SAR," 7/30/96

Ronald Graves; "Information Validation Form, RDG.3 IVF-Chapter 3, June 13, 1996

Calculations 
WHC-SD-WM-CN-073, REV. 0

\subsection{12 Mixing of Incompatible materials - Tank Pressurization}

This accident involves a mistransfer of incompatible materials into a waste tank that could lead to overpressurization and release of both radioactive and toxic chemicals to the environment. This addition may lead to a simple overpressurization which is relieved by the ventilation system or it may lead to catastrophic failure of the vessel. The likelihood of a mixing of wastes resulting in tank failure has been demonstrated to be beyond extremely unlikely and no additional analysis will be performed. [Reynolds].

The hazard analysis perfonned for incompatible waste issues identified a mistransfer of incompatible waste in a DCRT leading to a chemical reaction release radioactive and toxic aerosols as an accident with potentiaily significant onsite consequences. Although transfers within the waste tank system will not lead to exothermic reactions, additions of materials from processing facilities or the SST system may lead to exothermic reaction. The most severe addition has been determined to the be that addition of acid or acidic waste to a very basic waste tank solution.

A DCRT is a short-term waste storage facility that consists of a tank and related equipment. A DCRT consists of an underground concrete structure that contains a filter pit, pump pit, and a vault in which a catch tank is instailed. The DCRT is used for interim storage of liquid waste and as a valve pit for waste transfer operations. Components for mixing steam and water for backflushing and decontarmination operations are located in a nearby flush pit.

The exhaust fans in the tanik ventilation systems maintain a negative air pressure inside the primary tank to prevent unfiltered air emissions from escaping from the DCRT/catch station. The air exhausted from the tank passes through a heater, prefilter, HEPA filters, and is monitored for radiation before being released into the environment.

The neutralization of nitric acid with sodium hydroxide leads to the following exothermic chemical reaction.

$$
\mathrm{NaOH}(\mathrm{aq})+\mathrm{HNO}_{3} \rightarrow \mathrm{NaNO}_{3}+\mathrm{H}_{2} \mathrm{O}
$$

The hear of reaction for the neutralizarion reaction is given by:

$$
\Delta \mathrm{H}_{\mathrm{r}}=\sum_{\text {products }} \Delta \mathrm{H}_{\mathrm{f}}^{\circ}-\sum_{\operatorname{rac} \mathrm{con}} \Delta \mathrm{H}_{\mathrm{f}}^{\circ}
$$

which yields $-57.7 \mathrm{~kJ} / \mathrm{g}$-mole for this reaction

To assess the potential consequences in the absence of engineered, mirigarive systems, a transfer of 110 gallons of 57 weight percent nirric acid into a DCRT was analyzed. A nitric acid transfer was used because:

- Processing facilities contain small amounts of nitric acid, mostly in laboratory scale or 55 gallon drums used for decontamination purposes. A 110 gallon transfer of 57 wt \% would bound the transfer from any single source, since this represents the maximum amount of nitric acid allowed to be stored in the connected processing facilities.

- Processing facilities are required to neutralize acidic wastes prior to transfer. Unneutralized wastes would be much more dilute than nitric acid. The only 
WHC-SD-WM-CN-073, REV. $O$

Caic Note M-CLC.G-00237 (Rev 3)

Sheet 14

facility identified which has substantial amounts of acidic waste was 222-S

labs which has a 4000 gallon tank which is connected to the tank farm.

Waste contained in this tank could have an unnuetralized $\mathrm{pH}$ of 1

$\left(\left[\mathrm{H}^{+}\right]=.1 \mathrm{M}\right)$.

The accident scenario assumes that the DCRT contains waste which is sufficiently basic to completely neutralize the incoming acid transfer. This ensures that the maximum heat of reaction per mole of inconaing acid is generated and maximizes the hearup of waste. The hydroxide content is taken to be at the maximum allowed under DCRT corrosion control limits (10 M OH). The material at risk is thereby defined by this amount.

\section{[RYAN]}

The volume for DCRT 244-A is used for this analysis, 16280 gal since this minimizes the vapor space volume and maximizes the concentration of derosols released to the environment.

The damage ratio is determined by the fraction of waste which vaporizes as a result of the exothermic reaction. The waste in the DCRT is assumed to be at $200^{\circ} \mathrm{F}\left(93^{\circ} \mathrm{C}\right)$. This is the maximum allowable temperature for DCRTs based on thermal strucnural considerations. The boiling point is taken to be $212^{\circ} \mathrm{F}\left(100^{\circ} \mathrm{C}\right)$. Energy generated from the chemical reaction will first heat up the waste and ther lead to boiling. No heat losses are assumed from the tank or from the ventilation system. The ventilation system is assumed to continue to operate during this accident, thereby maximizing the release rate of radionuclides and toxics. No credit is taken for any of the HEPA filters in the ventilation system. The airborne release fraction for boiling of $2 \times 10^{-3}$ was used for this analysis.

This accident has been analyzed as being an ancipipated event.

The material at risk to be released is based on the maximum radionuclide concentration for one-third double shell solids and two thirds double shell liquids. In practice, there is very little DST solids transferred into DCRTs. Therefore, this is a very conservative assumption.

Table DCRT-1 contains a list of radiological and toxicological consequence value for the release from the nitric acid addition. These consequence values are based on the boiling of waste from a liquid pool. Section 3.4.2.x provides a description the methodology used to calculate release from the boiling from liquid pools.

The unmirigated accident offsite consequence values shown in Table DCRT-1 are well within the risk evaluation guidelines as shown in Figure 3.3-x. Therefore, no DCRT scuctures, systems, or components have been designated as safety class.

In order to reduce the onsite consequences to within the evaluation guidelines, the HEPA filters will be designated safety significant $A$ mitigated analysis which included the HEPA filters was performed. A leak path factor of $5 \times 10^{-4}$ was applied for the HEPA filters (99.95\% effectiveness). This brings the onsite mitigated consequences within the evaluation guidelines.

Required administrative controls are that all incoming wastes to the TWRS must be neutralized and that the waste compatibility program must be in place.

References:

22 of 5859 
WHC-SD-WM-CN-073, REV. 0

Calc Note M-CLC-G-00237 (Rev 3)

Sheet 15

DOE-HDBK-3010, 1994, Airborne Release Fractions/Rates and Respirable Fractions for Nonreactor Nuclear Facilities, U.S. Department of Energy, Washington, D.C.

D. A. Reynolds, "Review of Chemical Mechanisms for Tank Dome Collapse from Incompatible Waste Mistransfer,". WHC, to be issued.

RYAN, G.W, 1994, "OPERATIONAL SUMMARIES FOR

AUXILIARY FACILITHES" WHC-5D-WM-5ARR-OOB,

REV. O, WESTINGHOCSE HANFORD COMPANP,

PICHAAND, WA. 
Table 3.3.X.C-1. Accident Consequences and Frequencies for Chemical Reaction in DCRT Chemical Reaction in DCRT.

\begin{tabular}{|c|c|c|c|c|c|c|c|c|}
\hline \multirow{4}{*}{ Accident } & \multicolumn{8}{|c|}{ Consequences } \\
\hline & \multicolumn{4}{|c|}{ Radiological (Sv) } & \multicolumn{4}{|c|}{ Toxicological } \\
\hline & \multicolumn{2}{|c|}{ Unmitigaled } & \multicolumn{2}{|c|}{ Mitigaled } & \multicolumn{2}{|c|}{ Unmitigned } & \multicolumn{2}{|c|}{ Mitigaled } \\
\hline & Ontito & Offsite & Ontile & Oftrite & Orisite & Offrie & Onsin: & OII vite \\
\hline $\begin{array}{l}110 \text { al } 57 \text { m } 9 \\
\text { Nituic Acid } \\
\text { mintranster }\end{array}$ & $\frac{26}{267}$ & $1.8 \mathrm{~B}-\overline{04}$ & 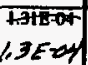 & $\begin{array}{l}\text { 39B-Ob } \\
9.05-08\end{array}$ & $\begin{array}{l}3.5 \\
4.0\end{array}$ & $\begin{array}{l}1798-62 \\
1,84-02\end{array}$ & $\begin{array}{l}15906 \\
.82\end{array}$ & 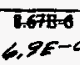 \\
\hline $\begin{array}{c}4000 \text { gal } \\
\text { transfer, } 222-s \\
\text { waute, pH }=1\end{array}$ & 0 & 0 & & 5 & $\overline{0}$ & 0 & & \\
\hline
\end{tabular}


TABLE 3.3.X.A-2. Defense -In-Depth Controls for Chemical Reaction in DCRT

\begin{tabular}{|l|l|l|}
\hline Control & Function & Remarks \\
\hline $\begin{array}{l}\text { Tank Farm Waste } \\
\text { Compatibility Program }\end{array}$ & $\begin{array}{l}\text { Ensures that waste transfers are compatible with } \\
\text { regard to criticality, flammable gas generation, } \\
\text { heating, organics, and other safety and } \\
\text { operational concerns. }\end{array}$ & $\begin{array}{l}\text { K. D. Fowler, Tank Farm Waste } \\
\text { Transfer Compatibility Program, } \\
\text { WHC-SD-WM-OCD-015, Rev. 1, } \\
\text { April 24, 1995 }\end{array}$ \\
\hline $\begin{array}{l}\text { Waste Transfer procedural } \\
\text { controls }\end{array}$ & Ensure correct routing lineup. & \\
\hline $\begin{array}{l}\text { Neutralization of all acid } \\
\text { waste transfers prior to } \\
\text { shipment to DCRT. }\end{array}$ & $\begin{array}{l}\text { Ensure that no acidic waste is transferred to } \\
\text { DCRT. Corrosion control and energetic reaction } \\
\text { prevention. }\end{array}$ & \\
\hline
\end{tabular}




\section{Response to Comments: Mixing of Incompatible Materials - Tank Pressurization}

1-10. Incorporated

11a. Incorporated

11b. Since we have no safery class SSCS or technical specifications, there is no requirement for a Section 3.4 write-up. All controls for this accident are related to worker protection, not offsite dose.

11c. There is no energetic event as a result of this accident, but rather a heatup/boiling of liquids. There is no pressurization event that will not be relieved by the ventilation system. Note that I have assumed that the DCRT waste tank is in communication with the vault, although I know that there is not a close coupling berween the two vessels. If I assumed there was not communication between the two, the pressurization would be important, but there would be minimal release to the environment unless the vessel failed.

12. Comment recognized.

13. See response to $11 \mathrm{~b}$.

, 14. See response to $11 \mathrm{~b}$. 
$1933 \mathrm{Jgdwin}$ A venue, Suite 135. Richland, WA. 99352

509-943-3634 Fax: 509-946-7365

Date: $7 / 30$

From:

Leaig Larro

To:

Ron Graves

Company: wsisp

Fax No.:

Phone No.:

Total pages: 29

Comments:

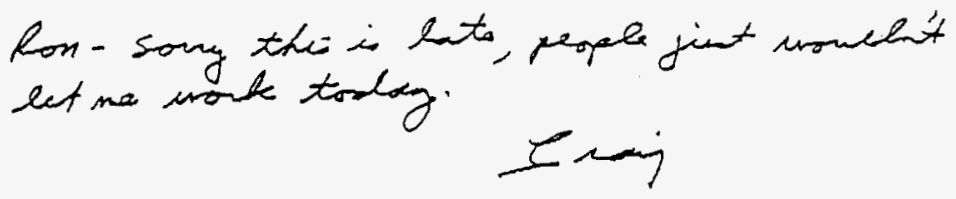


WHC-SD-WM-CN-073, REV. 0

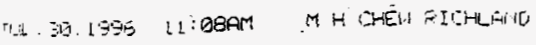

Pon,

Attached please find:

(a) pear review comments for "Pipeline Break from Excavation"

(b) peer review coments for "Addition of Incompatible Material to Waste Leading to Release of Toxic Vapors"

(c) peer review comments for "Mixing of Incompatible Materials-Tank Pressurization"

(d) Selected cantrols for Hixing of Incompatible Materials - Tank Pressurization"

(e) example control tables from the Brett Hall spray release accident

(f) SARR-016, Rev. $2 \times / Q$ values - these reflect the change in the site boundary to the near side of the Columbia River.

(g) SARR-011, Rev. 2 sum-of-fraction values that aiso reflect the change in $x / Q$.

Per Dirk Leach, the following work is required.

1) Priority 1 - Calculation Note Revtsions: read the peer review comments and determine what, if any, revisions to the calculation notes are required. Verify $X / Q$ and sum-of-fractions values per $(f)$ and $(g)$ above. Make necessary revisions.

Due date $=8 / 6$

2) Priority \#2 - Revised FSAR Text: revise section write-4DS per peer review comments.

Oue date $=8 / 13 \quad(509)$

If you have any questions, give me a call at 943-3634, or 373-3469, or page at 543-0502. If you have questions an the spray/pool consequences, calt Brett Halt at $376-3093$.

Craig 


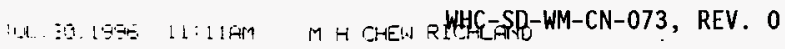

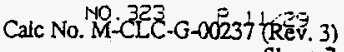

Sheet 2

$12^{4}$

(c) Peer Leview Comnents.

"Incumpat Waste- Tank Pressurigntin

29 of 5859 
PEER REVIEW COMMENTS

MIXNG OF INCOMPATIBLE MATERLALS - TANK PRESSURIZATION

1) sheer 13, general fSAR

The official section number is 3.3.2.3.2.2.12

The official section title is "Mixing of Incompatible Materials - Tank Pressurization

It is desirable to combine the mixing of incompatible waste - dome collapse analysis with this one. The approach would be to state in the introduction that the hazards analysis identified transfers of incompatible waste resulting in either dome collapse or pressurization. Then quickiy dismiss the dome collapse scenario by saying it is beyond extremely unlikely based on the Reynolds letter. Then present the pressurization analysis. This approach is desired as no analysis (i.e., scenario, source term, \&c) was performed for the dome collapse case.

The key comment in regards to the tank pressurization anaiysis is that you have provided an unmitigated analysis and identified controls, you need to also provide a mitigated analysis in which the controls are credited and show that we now meet the guidelines, e.g., the IEPA filters reducing the dose to $X$ and the TSRs on neutralization reduce the frequency to unlikely (or something like that).

2) sheet 13, 1st paragraph . Frs $A$ R

Need a different introductory paragraph, see comment $\# 1$ and $\# 5$

3) sheet 13,1 st paragraph, last sentence

This sentence is incomplete.

4) sheet 13, and and 3rd paragraphs frim

Suggest cambine these into a single summary paragraph describing a DCRT, then provide a reference to Chapter 2.0 for details.

5) sheet 13,4 th paragraph, 1st sentence Fiti

(a) Suggest Ist sentence be used as first sentence in a new opening paragraph associaced with the pressurization scenario. Follow it with a brief discussion of how you examined the various types of incompatibie wastes which could be added and how you ended up choosing $\mathrm{HNO}_{3}$ for your analysis.

(b) Suggest rephrasing to state "...chemical reaction and subsequent-release of..." 
6) sheet 13, 4th paragraph, and and 3rd sentences and associated equations Fitic

Suggest these be moved to sheet 14, 2nd paragraph (beginning "The damage ratio....") after ist sentence, as it is part of the source term calculation as opposed to the scenario.

7) sheet 13, last paragraph, 1st sentence

State that this is your "unmitigated analysis" in which no credit is taken for controls.

8) sheet 14, 2nd paragraph (beginning "The damage ratio....")

(a) Believe you mean the "source term" as opposed to the damage ratio.

(b) Provide basis for $150 \%$ temperature assumption.

(c) Give basis for 2E-3 release fraction and explain how it was applied (i.e., to the eatire contents of the tank? to the fraction that boiled? \&c).

(d) State the actual amount of material released by the accident.

9) Sheet 14,3 rd paragraph

Move this statement regarding frequency to the end of the unmitigated scenario discussion. Provide basis for assigning this frequency bin, e.g., buman arrot - failure to neutralize waste prior to transfer, \&c.

10) sheet 14,5 th paragraph

(a) Delete reference to 3.4.2.x and boiling liquids. You need to summarize in your source term discussion how you calculated the relcase, i.e., you applied a release fraction of $2 \mathrm{E}-3$ to something.

(b) Clarify that the numbers are the unmitigated consequences.

11) -. sheet 14 , 6th paragraph

(a) 2nd scutence, delete "... or safery significant." from end of sentence as you state in the aext sentence that the HEPA filters are safety significant,

(b) Attached is the Control Decision Record for this accident, need to state that because the onsite guidelines were exceeded, these controls were identified. Then you aeed to provide a mitigated analysis in which you take credit for these controls. The AC TSRs reduce the frequency of the event and the HEPA filters reduce the dose. This will require new dose calculations.

(b) For your mitigated analysis, You need to state that the pressures generated by the 
hear load/gases in the head space does not blow out your HEPA filters (assuming you know this to be true).

12) sheet 14,7 th paragraph

Attacied is the control decision record for this accident. There is ao TSR on $10 \mathrm{M}$ $\mathrm{NaOH}$, there is no TSR on temperature, there is no TSR on interfacing facility tanks.

13) sheet 14,8 th paragraph

The controls you have identified as defense-in-depth bave been selected as ISR level controls. See attached control decision record.

14) sheet 14,8 th paragraph

Need to provide summary tables of SSCs, TSRs, and Defense-in-Depth. See the Brett Hall spray release write-up for examples. 


\section{9-Aug-1996 04:44pm EST}

To: join. norkus

( john.norkusemailhub:srs.govgPMDEeSAEMS)

To: Dirk_S_Leachz HANEORD02B

(Dirk_S_Leach - HANEORD02BCccmail.pnI.govePMDE@SAEMS)

CC: Lankford_Ruffin

( Lankford_Ruffineccmail.pnI.govepMDECSAEMS )

From: Lankford Ruffint-NHC 338

( Lankford_Ruffins-WHC338eccmail.pnl.govePMDFesAEMS )

FNO - 3

John, this is a follow-up to the voice message I left you. As I stated. I accepted the bounding amount of $1000 \mathrm{gal}$. as indicated by the IVF answer to Ron Graves. However, I always try to use an upper number if this upper number allows more flexibility for "all". However, as I stated, the on $1 y$ external sacility that indicated it would store HNO-3 (if needed) for future use is B-plant. B-plant indicated that their new Interim Safety gasis will only allow for 110 gallons of nitric acid to be stored at the plant. Currently (about 2 months ago) B-Plant had less than 50 gallons of nitric acid. PFP (acronym for another facility) indicated that it currently has no HNO-3. However, if it did require some, it would also use 55 gal. drums. REP stated that no more than two $55 \mathrm{gal}$. drums max. would ever be needed to add to there sending tank (D-5), which sends its" waste to tank faxm's DCRT. So, my opinion would be that you use the maximum number you can to bound the accident. If this is not acceptable, then use the 150 gallons which is allowed by the safety basis for B-Plant, or the 600 gallons limit you discussed with me on the telephone. If you need to reach me, my number is 509-373-3035. I' 11 be back next Fednesday (9/4).

Lankford 
WHC-SD-WM-CN-073, REV. 0

INTER-OFFICE MEMORANDOM

Savannah River Site

17-Jun-1996 01:41pm EST

To: john.norkus

( john .norkusemailhöb.srs.govePMDEesAEMS )

From: Ronald D Ron Graves

( Ronald_D_Ron_Graveserl.govepMDEeSAEMS )

\section{M-ansfers to DCRT or DST}

Ron,

B Plant currently uses one transfer zoute out of plant. This transfer: route is used to move liquid low level waste from 3 plant to Tank Fam underground storage. Once the pipeline leaves the wall of $B$ plant it becomes rank Farms rzansfer line. Tank Eams takes control of all route changes from that point. So the ouestion of whether $B$ Plant

3 transfers to a DCRT or to a DST could be better answered by East rank Earm Engineering.

Duane 


\section{INTER-OFEICE MIMORANDUM}

Savannah River Site

14-Jun-1996 06:06pm EST

To: john, norkus

( john.norkusemailhüi.srs.govepMDFesaEMS)

From: Ronald_D_Ron_Graves

(Ronald_D_Ron_Graveserl.govePMDFCSAEMS)

\section{Conment/response to acidic twanster to RST}

It is difficult to agree to the statement that a maximum of 1,000 galions of nitzic could be transferred to a DST. The B plant safety basis says that we have three vertical eight thousand gallon nitric acid tanks. Today, the tanks are empty and there are no plans to refill them. The chemical headers that would deifver the nitric acid are also empty. Curzently the plant has less than 50 gallons of nitric acid. The new Interim Safety Basis that is being written allows for 110 gallons to be stored at the plant.

In reality the chance of transferring more than 1000 gallons of nitric to a DST is extremely low when considering the lack of nitric. administrative preventatives and procedural preventatives. The point is, 3 plant has the ability to store more than 1000 gallons of nitric. If the quantiy of nitzic exists then the possibility of transferring the quanity exists.

Duane 


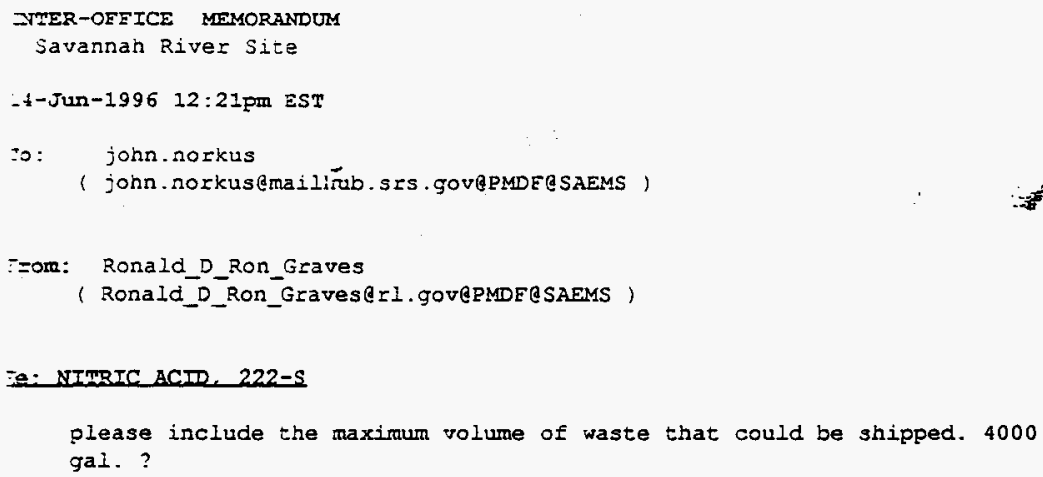

NITRIC ACID CANNOT BE TRANSEERRED DIRECTIY EROM THE 222-S IAAB TO TANK BARMS'. WE DO NOT STORE NITRIC ACID IN BULK EORM.

OUR WASTE IS ACIDIC (PH OE AROUND I) BEFORE WE TREAT IT. 
INTER-OEEICE MEMORANDUM

Savannah River Sice

12-Jun-1996 11:52am EST

To: john.norkus

( john norkusemailfub.srs.govePMDECSAEMS)

From: Ronald_D_Ron_Graves

( Ronald_D_Ron_Graveserl.govePMDFeSAEMS )

\section{Witric to 244-7x}

Ron,

Here is the information you requested in general, if you need more: specific information, give me a call.

Greg

1. Physically our Nitric Tank isn't connected to our waste tank that is shipped to tank farms. We would have to install some type of jumper requiring ECNs, USQs, workpackages, etc.

2. We no longer have a nitric acid in bulk. Our bulk aitric acid tank was emptied and shipped off site 6 weeks ago. Our furure needs (in any) for nitric acid will be met by using 55 gallon drums.

3. Our waste lines aren't connected directly to the tank that ships to tank farms. All radioactive liquid waste goes to a separate tank, and is sampled for hydroxide ion, solids, Pu content, before transferring to our shipping tank to tank farms. Once it is in our shipping tank to tank farms, hydroxide ion, solids, Pu content are verified again before shipping. Plus we couldn't ship anything to tank farms without them knowing because they have an interlock on our pumps. There would have to be many failures before a acidic shipment could be sent.

John this is a reply I received from PFP concerning nitric acid inventory. 


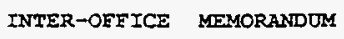

Irom: Ronald_D_Ron_Graves

( Ronald_D_Ron_GraveserI.govepMDFeSAEMS )

\section{Ne Potential for Niteic Acid to Tank ranms from puRvX}

Ron,

Currently, PUREx is in the process of sending the last batch of solution from Tank U3 to Tank Earms (Tank 105-AW). This transfer solution will contain essentially contaminated water. This wiIl be the final transfer of solution of from a PUREX waste tank to Tank Earms. Also, pUREx does not have an inventory of nitric acid that could be added this waste tank. It is not likely that PUREX will have

1" any acid inventory in the future due to the deactivation of the PUREX facility.

Sean Eiholzer

$P$ zocess Engineer

PUREX Surveillance Team 


\begin{tabular}{|c|c|c|c|c|c|c|c|c|c|c|c|c|c|}
\hline & A & B & c. & D & E & $F$ & 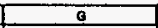 & H & $I$ & J & $\mathrm{K}$ & $t$ & $M$ \\
\hline 1 & & Hf (kcal/o mole) & & Density & 1000 & $\times 0 / \mathrm{m}_{3}$ & ULLD, Inn, DST, liq & $6.10 E+03$ & Sva & Tank volume & $0.1 \mathrm{\theta E}+04$ & 1 & \\
\hline 2 & HNO 3 & -49.21 & & CP & 4200 & J/kg K & ULD,ing,DST,liq & 0.068 & Sv-m3/s-1 & & & & \\
\hline 3 & $\mathrm{NaOH}$ & -112.193 & & hfo & $2.28 E+08$ & $\mathrm{~J} / \mathrm{kg}$ & ULD, inh, DST, sol & $5.30 E+05$ & Svil & Ventllatlon rate & 250 & sfm & \\
\hline 4 & NaNO3 & -106.88 & & & & & ULD, Ing,DST, sol & 0.48 & $\mathrm{~Sv}-\mathrm{m} 3 / \mathrm{s} \cdot 1$ & & 118 & $1 / 18$ & \\
\hline 5 & $\mathrm{H2O}$ & -68.3174 & & & & & Solids frac & 0.33 & & & & & \\
\hline 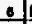 & Hrxn & -13.7944 & kcal/amol & & & & $x / 0$, onsite & 3.41E-02 & $8 / \mathrm{m} 3$ & OST llquid onsite limit & $1.00 E+04$ & $B \cap$ & \\
\hline 2 & Anxn & $.5 .78 E+04$ & J/g-mole & & & & $x / 0$, offsite & 2.83E-05 & $\mathrm{s} / \mathrm{m} 3$ & DST liquid olfsite limis & 0.4 & $E A$ & . \\
\hline 8 & & 5 & $42 E$ & $P 1 N$ & $C A \angle C$ & & R,onsite & $3.30 E-04$ & $\mathrm{~m} 3 / \mathrm{s}$ & DST solids onsite limit & $1.80 E+04$ & $5 A$ & \\
\hline 9 & Waste teme & 93.33 & C & FOR & $4 \subset \times n$ & & A, offorite & $2.70 \mathrm{E}-04$ & $\mathrm{~m} 3 / \mathrm{s}$ & DST solids offrsite limit & 190 & $E A$ & \\
\hline 10 & Boiling tomp & 100 & c & & & & Dose limit onsite & 0.5 & rem & & & & \\
\hline 11) & & & & & & & Dose limlt of tsite & 0.1 & rem & & & & \\
\hline 12 & & & & & & & & & & & & & \\
\hline 13 & & Acld & & & Ease Volume & & & Reaction & & & Heat up anergy & Mass ovapora & ted $(\mathrm{Tw}$ \\
\hline 14 & Volume(gal) & Vol (I) & Molarity & Molarity & to neutrallze(1) & (gai) & Total volume, $\mathrm{m} 3$ & \begin{tabular}{|l|} 
energy $(J)$ \\
\end{tabular} & Delta $Y(K)$ & Boil? & (J) & $\mathrm{kg}$ & vol(m3) \\
\hline 15 & 110 & 416.4 & 12.2 & 5 & 1010 & 268.43 & 1.43 & $2.93 E+08$ & 48.77 & boilling & $4.01 E+07$ & 112.2 & 0.11 \\
\hline 16 & 110 & 416.4 & 12.2 & 10 & 508 & 134.21 & 0.92 & $2.93 E+08$ & 75.67 & boilling & $2.59 \mathrm{E}+07$ & 118.5 & 0.12 \\
\hline 17 & 4000 & 15141.6 & 0.1 & 10 & 151 & 40.00 & 15.29 & $8.75 E+07$ & 1.36 & heat up & $8.7 E+07$ & $0.00 E+00$ & 0.00 \\
\hline
\end{tabular}




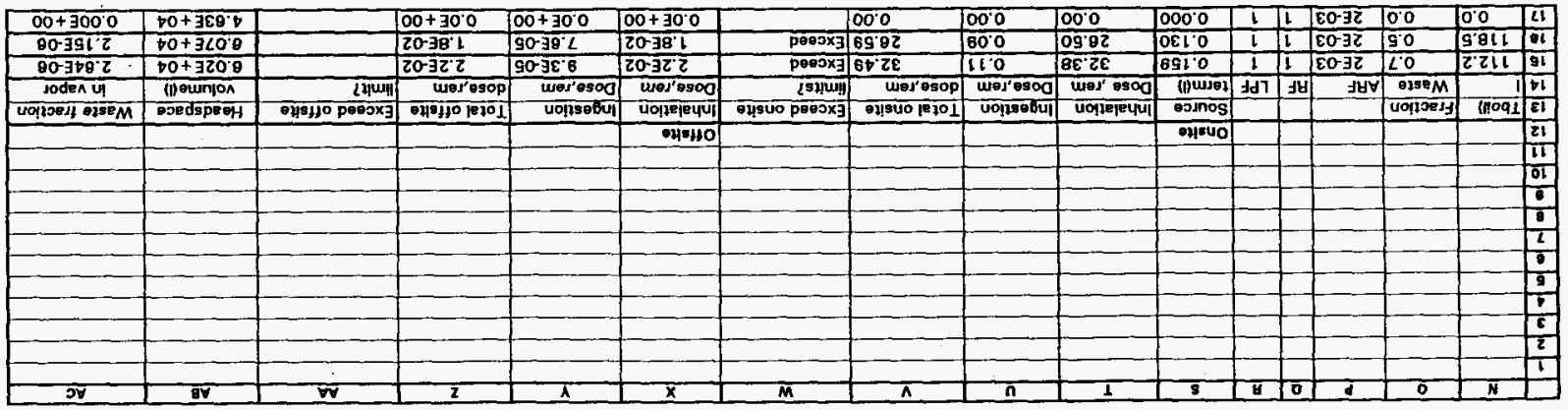


WHC-SD-WM-CN-073, REV. 0

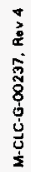

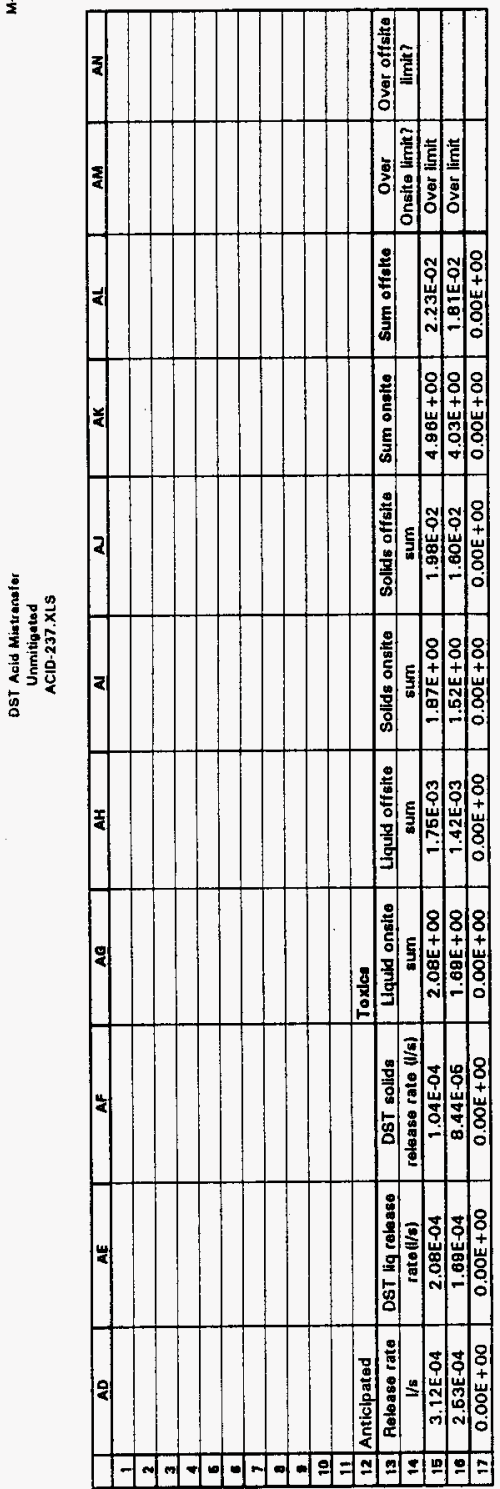

8 


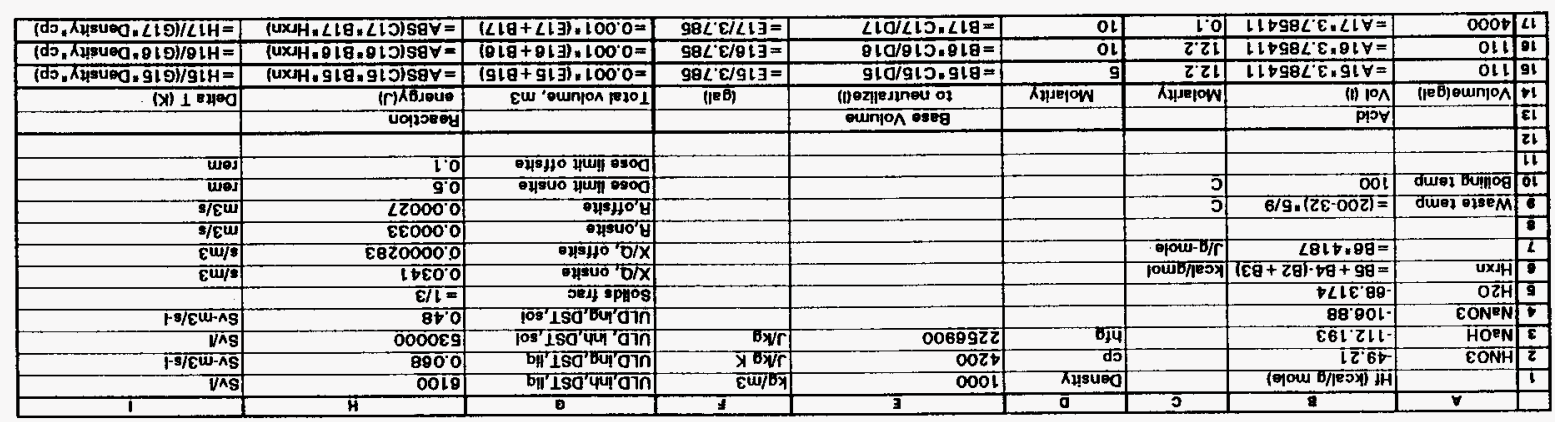




\begin{tabular}{|c|c|c|c|}
\hline & J & $\mathrm{K}$ & 2 \\
\hline 1 & Tank volume & 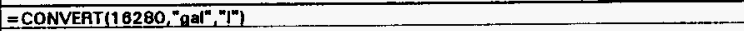 & 1 \\
\hline \multicolumn{4}{|c|}{ 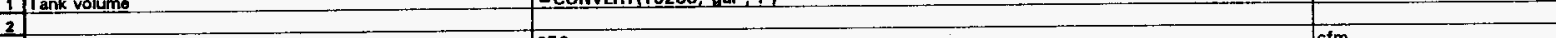 } \\
\hline 3 & Ventilation rate & 250 & $\mathrm{cfm}$ \\
\hline 4 & & $=26.32 * K 3 / 80$ & $1 / \mathbf{s}$ \\
\hline \multicolumn{4}{|c|}{\begin{tabular}{l|l}
4 & - \\
&
\end{tabular}} \\
\hline 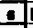 & DST Hiquid onstie limit & 10000 & $6 \lambda$ \\
\hline 7 & DST Hquald of fsitte limh & 8.4 & $8 / 1$ \\
\hline 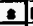 & DST solkds onsite Himlt & 18000 & 81 \\
\hline . & DST solids offsite limit & 190 & $\underline{s i}$. \\
\hline \multirow{2}{*}{\multicolumn{4}{|c|}{$\frac{10}{11}$}} \\
\hline & & & \\
\hline 13 & & Heat up energy & Mass gvaporatod (Tw = Tboil) \\
\hline 14 & Boll? & (J) & $\mathrm{kg}$ \\
\hline 15 & =IF(115 + Waste temp > Boiling temp, "bolling", "heat up") & 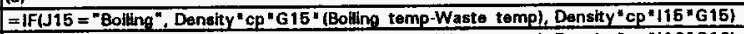 & $=(\mathrm{H} 16-\mathrm{K} 15) \mathrm{hfg}$ \\
\hline 10 & $=\mid F(116+$ Waste temp > Boiling tomp, "boilling", "heat up") & 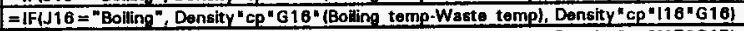 & $=(\mathrm{H} 16 \cdot \mathrm{K} 16) \mathrm{hfg}$ \\
\hline 17 & $=I F(117+$ Waste temp $>$ Boiling temp, "boilling", "heat up") & 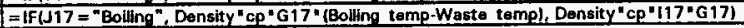 & $=(H 17-K 17) \mathrm{Mfg}$ \\
\hline
\end{tabular}

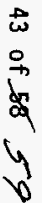


ACID-237.XLS

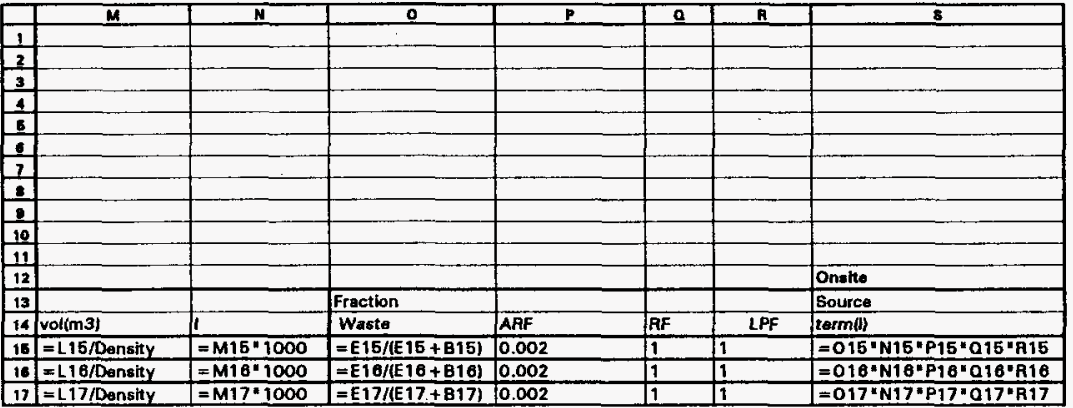


DST Acid Minteanafor

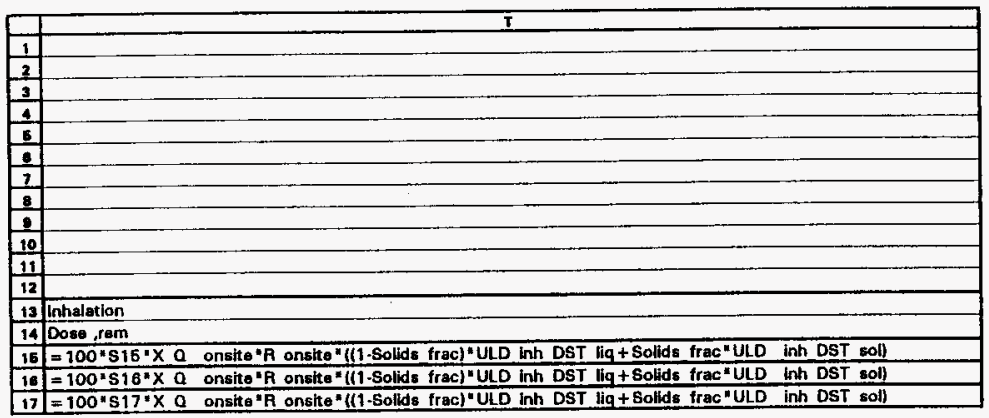


WHC-SD-WM-CN-073, REV. 0

ํ.

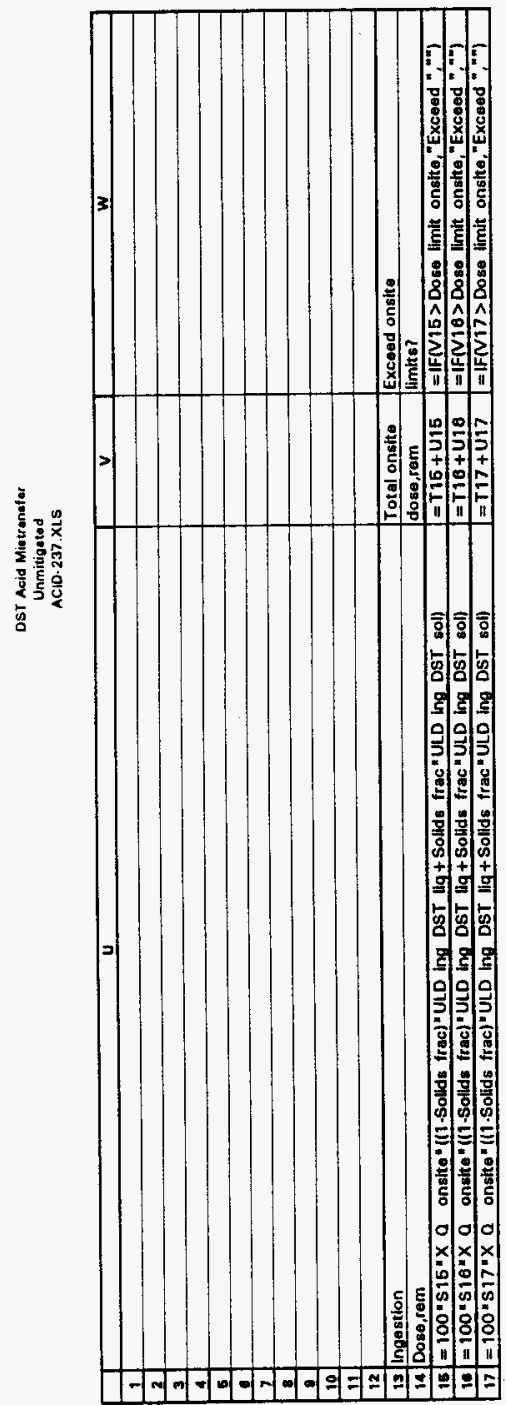

$\stackrel{5}{8}$ 


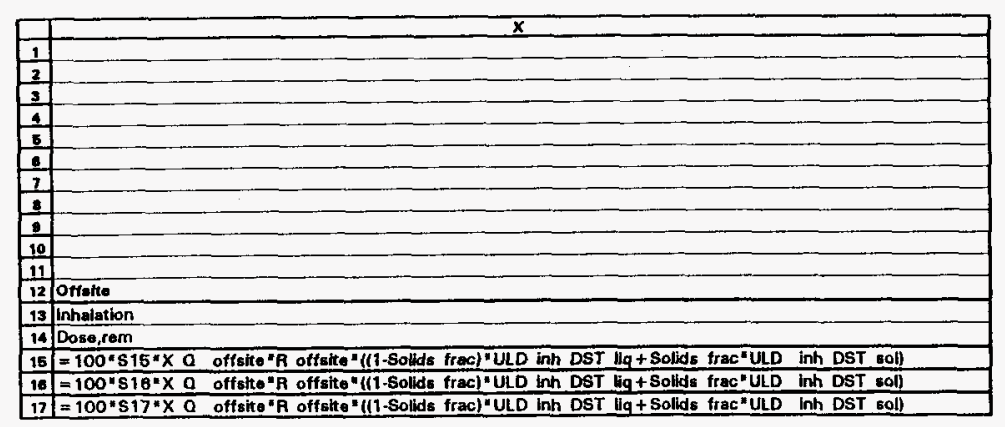

3
0
0
0
0 


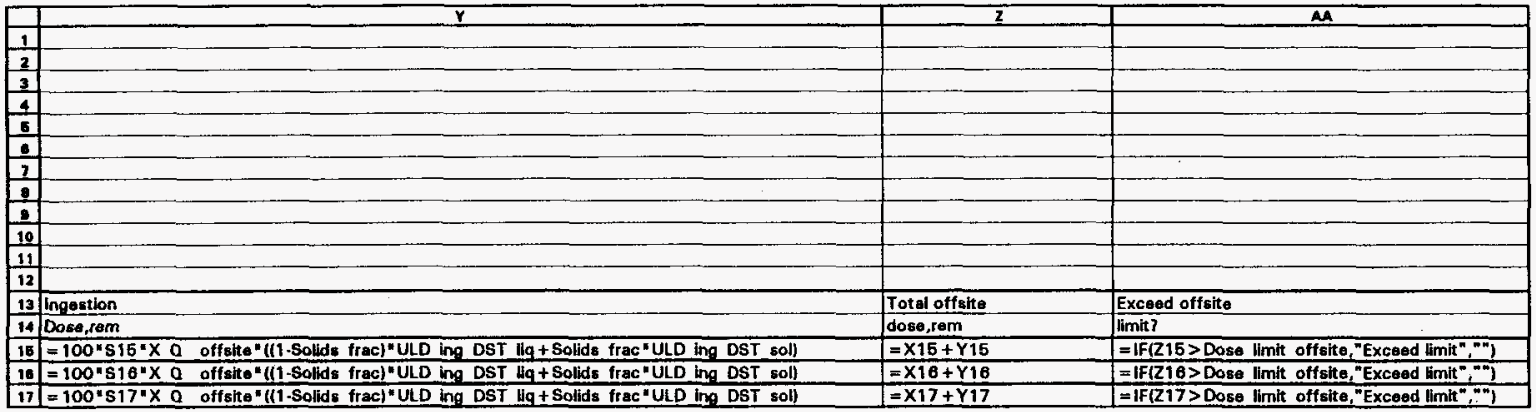

के
के
के
के 


\begin{tabular}{|c|c|c|c|c|c|c|}
\hline 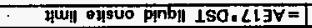 & JEग! spl|OS : $\angle L O V=1$ & (Dej) sp!los-1). $\angle 10 \forall=1$ & 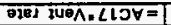 & $\angle L Q V I \angle I \bar{S}=1$ & 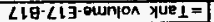 & (4) \\
\hline 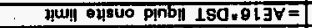 & JeI) splos.910Y= & (DE) SP\|IOS-1). & 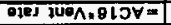 & 9เgV/gis $=$ & 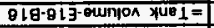 & था \\
\hline 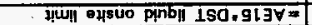 & 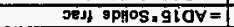 & 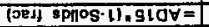 & ब1อ1 100 & gLaV/gis $=$ & 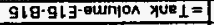 & 91 \\
\hline wris & 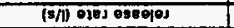 & $(3 / n) \operatorname{ejes}$ & 8 & Joden पा & (N)eumon & in \\
\hline क्युग0 pमnहत & spllos 150 & oseopo bi 1sa & 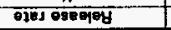 & 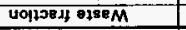 & อгеdgpe日H & Ei \\
\hline FPx०1 & & & pelediplutr & & & $2 i$ \\
\hline & & & & & & iii \\
\hline & & & & & & $\div$ \\
\hline & & & & & & 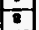 \\
\hline & & & & & & 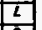 \\
\hline & & & & & & $\div$ \\
\hline & & & & & & $\div$ \\
\hline & & & & & & $\varepsilon$ \\
\hline & & & & & & 2 \\
\hline जण & JV & $\overline{3 y}$ & ov & कप & 夏 & $\square$ \\
\hline
\end{tabular}




\begin{tabular}{|c|c|c|c|c|}
\hline & AH & A & A & AK \\
\hline \multicolumn{5}{|l|}{1} \\
\hline \multirow{2}{*}{\multicolumn{5}{|c|}{$\frac{2}{3}$}} \\
\hline & & & & \\
\hline \multirow{2}{*}{\multicolumn{5}{|c|}{4}} \\
\hline & & & & \\
\hline \multicolumn{5}{|c|}{6} \\
\hline \multirow{2}{*}{\multicolumn{5}{|c|}{$\begin{array}{l}7 \\
8 \\
\end{array}$}} \\
\hline & & & & \\
\hline \multicolumn{5}{|l|}{10} \\
\hline \multirow{2}{*}{\multicolumn{5}{|c|}{$\frac{11}{12}$}} \\
\hline & & & & \\
\hline 13 & Liquid of fsite & Solids onsite & Solids offeste & Sum onsite \\
\hline 14 & sum & sum & sum & \\
\hline 15 & $=$ AE15 "DST Hquid offsite limit & = AF15 "DST solids onshe limit & =AF16"DST solids offsite limit & $=A G 15+A \mid 15+[$ 'ACID-237.XLS]Ammonia Raleasa'IE 17 \\
\hline 10 & $=A E 16$ DST liquid offelte limit & $=$ AF16 $10^{\circ}$ DST solds onsite limit & $=A F 16^{\circ}$ DST solids offsitte Hmit & $=A G 16+A \mid 16+[A C I D-237 . X L S \mid A m m o n i a$ Release'IE 18 \\
\hline 17 & $=$ AE $17^{*}$ DST liquid offsite limit & =AF17" OST solids onsite limit & $=$ AF 17*DST solids offsite limit & $=A G 17+\mathrm{Al17}+{ }^{\prime}[\mathrm{ACID} \cdot 237 . \mathrm{XLS}$ )Ammonia Release'IE 19 \\
\hline
\end{tabular}


DST Acid Mistrenefer

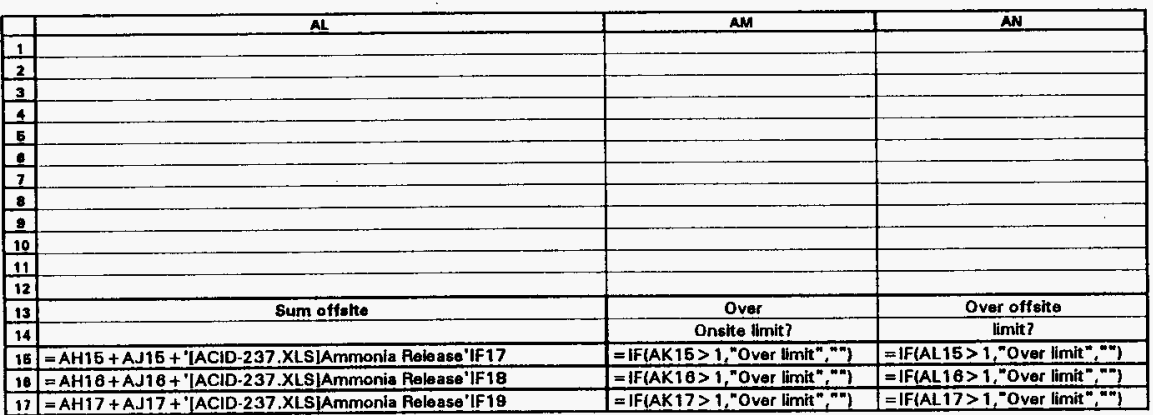




\begin{tabular}{|c|c|c|c|c|c|c|c|c|c|c|c|c|c|c|c|c|c|c|c|}
\hline $0000 \%$ & 9000.0 & 01 & 02000 & 66000 & 00 & 100 & 00 & $\angle 0+39 \angle \theta$ & dח 3004 & $408 \cdot 1$ & $\angle 0+39 L$ & $B C^{2} 91$ & ot & 191 & of & 100 & gibisi & 10000 & 92 \\
\hline $1000^{\circ} 0$ & 50000 & 0.1 & 02000 & $96+90$ & 9811 & 10 & g'011 & $20+3692$ & Buglog & 495 & $80+366 z$ & 860 & $\frac{981}{992}$ & 909 & of & $\mid z 210$ & tolt & $\frac{1011}{0+1}$ & 4 \\
\hline $1000^{\prime} 0$ & $9000^{\circ} 0$ & 01 & 02000 & $E 60<0$ & 2211 & 110 & 2211 & $\angle 0+310 t$ & $\frac{8 u \text { pog }}{j \text { jog }}$ & 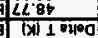 & 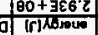 & 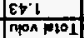 & $\frac{892}{(50)}$ & $\frac{9101}{(1) \text { expentou }}$ & रा? & 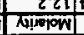 & (II) PN) & $\frac{0.11}{n+m+n}$ & $\frac{9 i}{9 i}$ \\
\hline Ditnos & & 베기 & 280 & 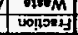 & hool = & 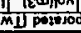 & Dos & Throve an $150 \mathrm{H}$ & 200 & & of & & & menton $\cos 8$ & & & 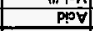 & & $\frac{31}{21}$ \\
\hline & & & & & & & & & & & & & & & & & & & $\varepsilon i$ \\
\hline & & & & & & & & & & & & & & & & & & & $\pi t$ \\
\hline & & & & & & & & & & & & & & & & & & & II \\
\hline & & & & & & & & & & 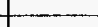 & & & & & & & & & $\frac{12}{6}$ \\
\hline & & & & & & & & & & $m$ & & & & & & & & & 8 \\
\hline & & & & & & & & & & & & & & & & & & & $L$ \\
\hline & & & & & & & & & & . & & & & & & & IVפIIW & & 2 \\
\hline & & & & & & & & & & & & & & & & & & & 9 \\
\hline & & & & & & & & & & & & & & & & & & & $\frac{1}{\varepsilon}$ \\
\hline & & & & & & & & & & & & & & & & & & & 2 \\
\hline$\overline{8}$ & y & 0 & J & $\overline{0}$ & $\mathbb{N}$ & $\bar{n}$ & 1 & $\bar{x}$ & & I & $\boldsymbol{H}$ & 0 & 1 & $\mathbf{3}$ & $\bar{a}$ & 3 & 8 & 7 & 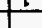 \\
\hline
\end{tabular}

sาx $<\varepsilon 2$ -

$\rightarrow$ nes. $28200-2020 \mathrm{~N}$

pasucher 


\begin{tabular}{|c|c|c|c|c|c|c|c|c|c|c|c|c|c|c|c|}
\hline & $T$ & U & $\bar{v}$ & $\mathbf{w}$ & $\bar{x}$ & $\bar{Y}$ & $\bar{Z}$ & $\overline{A A}$ & $\mathbf{A B}$ & $\overline{A C}$ & $\mathbf{A D}$ & AE & $A F$ & $\mathbf{A G}$ & AH \\
\hline 1 & & & & & & & & & & & & & & & \\
\hline 2 & & & & & $\therefore$ & & & & & & & & & & \\
\hline 3 & & & & & & & & & & & & & & & \\
\hline 4 & & & & & & & & & & & & & & & \\
\hline E다 & & & & & & & & & & & & & & & \\
\hline 6 & & & & & & & & & & & & & & & \\
\hline 7 & & & & & & & & & & & & & & & \\
\hline$\frac{8}{8}$ & & & & & & & & & & & & & & & \\
\hline$\frac{9}{10}$ & & & & & & & & & & & & & & & \\
\hline$\frac{10}{11}$ & & & & & & & & & & & & & & & \\
\hline 12 & & & & & & & & & & & & & & & \\
\hline 13 & & & & & & & & & & & & & & Toxics & \\
\hline 14 & Inhelution & Impontion & Total ongit & Excoed ongitg & inthelation. & ingestion & Totel offerise & Exceed offitite & Hoadepace & Wasts fraction & Raleose rate & DST liq release & DST solide & Liquid onsite & Liquid offenite \\
\hline 15 & Dose, rem & \begin{tabular}{|l|} 
Dose.rem \\
\end{tabular} & doser, rem & tirnits? & Dosen,rem & Doseram & doser rem & limit? & \begin{tabular}{|l} 
volumelli \\
\end{tabular} & in vepor & $v_{1}$ & rata(1/v) & relosese rato (V/s) & sum & sum \\
\hline 18 & $1.82 \mathrm{E}-02$ & 5.57E-05 & $1.82 \mathrm{E}-02$ & & $1.10 \mathrm{E}-05$ & $4.63 E-08$ & 1.10E-05 & & $6.02 E+04$ & $1.32 E-09$ & $1.56 \mathrm{E}-07$ & 1.04E-07 & $5.20 E-08$ & $1.04 \mathrm{E} .03$ & 8.74E-07 \\
\hline 17 & $1.32 \mathrm{E}-02$ & 4.56E-05 & $1.33 E-02$ & & 8.00E-06 & 3.79E-08 & $9.03 \mathrm{E}-08$ & & $6.07 E+04$ & $1.07 \mathrm{E}-09$ & $1.27 \mathrm{E}-07$ & $8.44 E-08$ & $4.22 \mathrm{E}-\mathrm{CO}$ & $8.44 E-04$ & $7.09 \mathrm{E}-07$ \\
\hline 18 & $0.00 E+00$ & $0.00 E+00$ & $0.00 E+\infty$ & & $0.00 E+\infty$ & $0.00 E+00$ & $0.00 E+00$ & & $4.63 E+04$ & $0.00 E+00$ & $0.00 E+\infty 0$ & $0.00 E+00$ & $0.00 E+00$ & $0.00 E+00$ & $0.00 E+00$ \\
\hline
\end{tabular}




\begin{tabular}{|c|c|c|c|c|c|c|}
\hline & & $00+300^{\prime} 0$ & $00+3000$ & $00+3000$ & $00+3000$ & \\
\hline & & 70-36:8 & $10^{3} 302^{\prime} 8$ & 90.320 .8 & t0.308 L & \begin{tabular}{|l|}
21 \\
1 \\
\end{tabular} \\
\hline & ind & $60-3898$ & $00+3101$ & $90-388.6$ & DO-JgE' 6 & $\frac{91}{91}$ \\
\hline 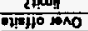 & 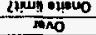 & 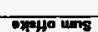 & 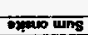 & काiflo sptos & 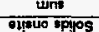 & $\frac{91}{t}$ \\
\hline & & & & & & ह1 \\
\hline & & & & & & 21 \\
\hline & & & & & & it \\
\hline & & & & & & $\frac{01}{8}$ \\
\hline & & & & & & $\frac{8}{8}$ \\
\hline & & & & & & \\
\hline & & & & & & 9 \\
\hline & & & & & & 8 \\
\hline & & & & & & $\frac{1}{\varepsilon}$ \\
\hline & & & & & & $\bar{z}$ \\
\hline NV & WV & iv & $x y$ & $\sqrt{7 \gamma}$ & IV & \\
\hline
\end{tabular}


DCRT Acid Mistransfer

M-CLC-G-00237, Rev 4 Ammonia Release

ACID-237XIS

\begin{tabular}{|c|c|c|c|c|c|c|c|}
\hline & $\mathbf{A}$ & B & $\mathbf{C}$ & D & $\mathbf{E}$ & $\mathbf{F}$ & $\mathbf{G}$ \\
\hline 1 & \multicolumn{7}{|c|}{ Ammonia release from acid addition to DCRT. } \\
\hline 2 & & & & & & & \\
\hline 3 & Tank & liquid (mg/l) & solid (mg/l) & source $(\mathrm{mg} / \mathrm{l})$ & & Vent. Rate (I/s) & 118 \\
\hline 4 & AW101 & 172 & & 172 & & ERPG-1 (mg/m3) & 17.25 \\
\hline 5 & AW105 & 170 & & 170 & & & \\
\hline 6 & AP103 & 3270 & & 3270 & & & \\
\hline 7 & AW101 & 247 & & 247 & & & \\
\hline 8 & AW102 & 61 & & 61 & & & \\
\hline 9 & AW105 & 894 & 1590 & 1123.68 & & & \\
\hline 10 & AW106 & 64 & & 64 & & & \\
\hline 11 & AY 102 & 2790 & & 2790 & & & \\
\hline 12 & SY101 & 146 & 2870 & 1044.92 & & & \\
\hline 13 & & & & & & & \\
\hline 14 & & & & & & & \\
\hline 15 & & & & & & & \\
\hline 16 & mass $\mathrm{NH} 3$ & Headspace Vol. & $\mathrm{C}$ in Headspace $(\mathrm{mg} / \mathrm{l})$ & & SOF Onsite & SOF Offsite & \\
\hline 17 & 260317.0936 & $6.02 E+04$ & $4.32 E+00$ & & $1.01 E+00$ & 8.37E-04 & \\
\hline 18 & 213012.8391 & $6.07 E+04$ & $3.51 \mathrm{E}+00$ & & $8.18 \mathrm{E}-01$ & $6.79 E-04$ & \\
\hline 19 & 10 & $4.63 E+04$ & $0.00 \mathrm{E}+00$ & & $0.00 E+00$ & $0.00 E+00$ & \\
\hline
\end{tabular}


ACID-237.XLS

\begin{tabular}{|c|c|c|}
\hline & A & $\mathbf{B}$ \\
\hline 1 & Ammonia release from acid addition to DCRT. & \\
\hline \multicolumn{3}{|c|}{ - } \\
\hline 3 & Tank & liquid (mg/) \\
\hline 4 & AW101 & 172 \\
\hline 5 & AW105 & 170 \\
\hline e & AP103 & 3270 \\
\hline 7 & AW101 & 247 \\
\hline 8 & AW102 & 61 \\
\hline 9 & AW10 $\overline{5}$ & 894 \\
\hline 10 & AW106 & 64 \\
\hline 11 & AY102 & 2780 \\
\hline 12 & SY101 & 146 \\
\hline \multicolumn{3}{|c|}{\begin{tabular}{l|l}
13 & \\
\end{tabular}} \\
\hline \multicolumn{3}{|l|}{14} \\
\hline \multicolumn{3}{|c|}{15} \\
\hline 16 & $\operatorname{mass} \mathrm{NH}_{3}$ & Headspace Vol. \\
\hline 17 & $=$ MAX $\$$ \$D \$4:\$D \$12]"'[ACID-237.XLS]Unmitigated'IN16"'[ACID-237.XLS]Unmitigated'lo15 & $=$ '[ACID-237.XLS]Unmitigated'|AB 15 \\
\hline 18 & 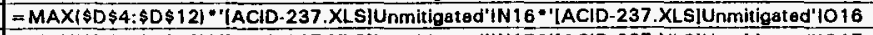 & $=[$ [ACID-237.XLS]Unmitigated'IAB 16 \\
\hline 19 & $=$ MAX $(\$ D \$ 4: \$ D \$ 12] *[$ (ACID-237.XLS]Unmitigated'IN17*'[ACID-237.XLS]Unmitigated'IO17 & $={ }^{\prime}[\mathrm{ACID}-237 \times \mathrm{XLS}$ U Unmitigated'IAB 17 \\
\hline
\end{tabular}




\begin{tabular}{|c|c|c|c|}
\hline 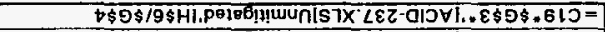 & & 16 (ब1)/6!V $=$ & $\overline{6} \mathbf{L}$ \\
\hline 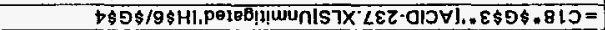 & & $(819) / 817=$ & 81 \\
\hline 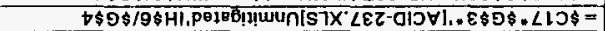 & & $(\angle L|\theta| / \angle L \forall=$ & Zl \\
\hline 91!suo jos & & 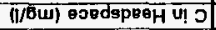 & 9! \\
\hline & & & $\overline{g i}$ \\
\hline & & & th \\
\hline & & & $\bar{\varepsilon} \mathbf{L}$ \\
\hline & 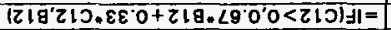 & $0<82$ & ZL \\
\hline & $\left(118^{\prime} \backslash 15 . \varepsilon \varepsilon^{\circ} 0+118 . \angle 0^{\circ} 0^{\circ} 0<1\right.$ <1ว) & & Il \\
\hline & 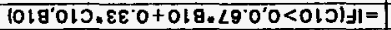 & & OI \\
\hline & $\left.168^{\prime} 60.8 \varepsilon \varepsilon^{\circ} 0+88_{0} . \angle 0^{\prime} 0^{\prime} 0<60 J\right)=$ & 0691 & 6 \\
\hline & $188^{\prime} 80.8 \varepsilon^{\circ} 0+8 \theta_{.} . \angle 9^{\circ} 0^{\prime} 0<80^{\prime} \mathrm{JI}=$ & & 8 \\
\hline & $\left.\angle \theta^{\prime} \angle O . \varepsilon \varepsilon^{\circ} 0+\angle 8^{\prime} \angle 9^{\circ} 0^{\prime} 0<\angle J\right) \exists I=$ & & $L$ \\
\hline & 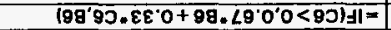 & & 9 \\
\hline & $\left.\left(98^{\prime} 90.8 \varepsilon^{\circ} 0+98^{\prime} . \angle 9^{\circ} 0^{\circ} 0<90\right)\right] 1=$ & & $\overline{9}$ \\
\hline & 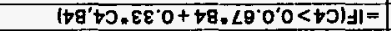 & & $t$ \\
\hline & (//Bwi ornos & (i//Bui) p! pios & $\bar{\varepsilon}$ \\
\hline & & & $\bar{z}$ \\
\hline & & & $I$ \\
\hline$\overline{\mathbf{3}}$ & a & 5 & \\
\hline
\end{tabular}




\begin{tabular}{|c|c|c|}
\hline & 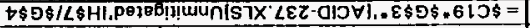 & 61 \\
\hline & 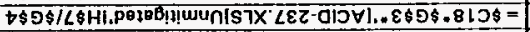 & 81 \\
\hline & 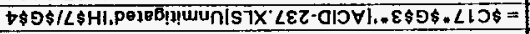 & 21 \\
\hline & eṇs!lo Jos & $\overline{\boldsymbol{g}}$ \\
\hline & & S! \\
\hline & & DI \\
\hline & & $\boldsymbol{\varepsilon}$ \\
\hline & & $\mathbf{z l}$ \\
\hline & & It \\
\hline & & $\overline{\mathrm{OL}}$ \\
\hline & & $\overline{6}$ \\
\hline & & 8 \\
\hline & & $L$ \\
\hline & & 8 \\
\hline & & $\overline{9}$ \\
\hline $9 \overline{2} .69^{\circ} 0=$ & (EU/6w) L-9dy & $\square$ \\
\hline 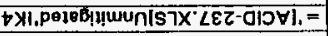 & (3/1) oloy zuen & E \\
\hline & & 2 \\
\hline & & $i$ \\
\hline $\mathbf{D}$ & $\exists$ & \\
\hline
\end{tabular}




$$
\text { WHC-SD-WIA-CNI-OMB, REV.O }
$$

\section{CHECKLIST FOR PEER REVIEW}

Document Reviewed:

Chemical Reaction in a DCRT, WHC-SD-WM-CN-073, Rev 0 , [a revised version of MCLC-G-00237, Rev 2].

Scope of Review:

Scope of Review: This review was 1 imited to confirming that the comments to $M$ CLC-G-00237, Rev 2, provided by this reviewer were dispositioned and/or incorporated into WHC-SD-WM-CN-073, Rev 0 , to my satisfaction.

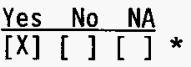

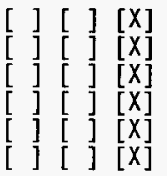

[X] [ ] [ ]

[ ] [ ] $[\mathrm{X}]$

[X] [ ] [ ]

$\left[\begin{array}{l}{[} \\ {[]}\end{array}\right]\left[\begin{array}{l}{[x]} \\ {[}\end{array}\right]$

$[$ [ ] $[$ ] $[\mathrm{X}]$

$\left.\begin{array}{llll}{[} & {[} & {[X]} \\ {[} & {[} & {[X]} \\ {[} & {[} & {[X]} \\ ] & {[} & {[X]}\end{array}\right]$

[ ] [ ] $[X]$

[ ] $[$ ] $[\mathrm{X}]$

[ ] $[\mathrm{X}]$ *
Previous reviews complete and cover analysis, up to scope of this review, with no gaps.

Problem completely defined.

Accident scenarios developed in a clear and logical manner.

Necessary assumptions explicitly stated and supported.

Computer codes and data files documented.

Data used in calculations explicitly stated in document.

Data checked for consistency with original source information as applicable.

Mathematical derivations checked including dimensional consistency of results.

Models appropriate and used within range of validity or use outside range of established validity justified.

Hand calculations checked for errors. Spreadsheet results should be treated exactly the same as hand calculations.

Software input correct and consistent with document reviewed.

Software output consistent with input and with results reported in document reviewed.

Limits/criteria/guidelines applied to analysis results are appropriate and referenced.

Limits/criteria/guidelines checked against references.

Safety margins consistent with good engineering practices.

Conclusions consistent with analytical results and applicable limits.

Results and conclusions address all points required in the problem statement.

Format consistent with appropriate NRC Regulatory Guide or other standards

\section{[X] [ ] [ ]}

Tom Tomaszewsk

Document approved.

Reviewer (Printed Name and Signatare)
$9 / 20 / 96$

Date

* Any calculations, comments, or rotes generated as part of this review should be signed, dated and attached to this checklist. Such material should be labeled and recorded in such a manner as to be intelligible to a technically qualified third party. NONE ATTACHED.

[ ] [ ] [X] Analysis entered inte analysis database Iom Tomaszewski /om Tomenom

(Printed Name and Signature)

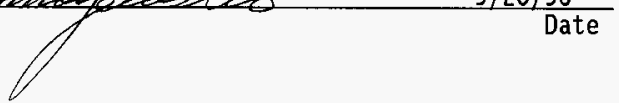




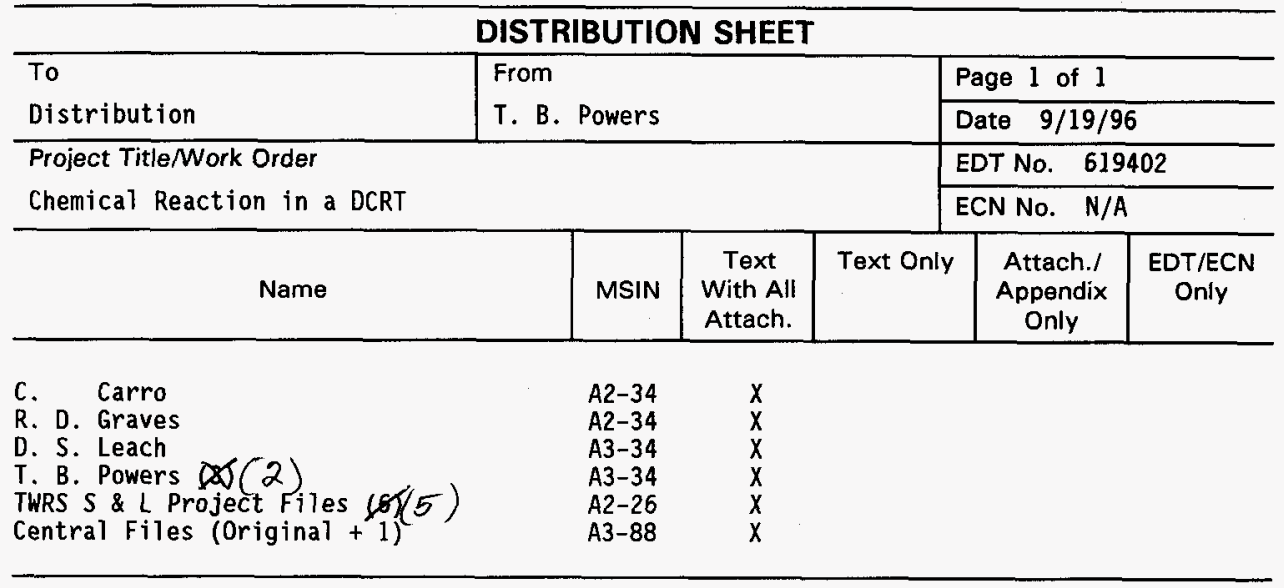

$$
\begin{aligned}
\text { *Advanad Distribution: } & \\
& \text { * TB Powers A3-34 } \\
& \text { *TURS Proj Files A2-26 }
\end{aligned}
$$

